\title{
Boninite and boninite-series volcanics in northern Zambales ophiolite: doubly vergent subduction initiation along Philippine Sea plate margins
}

\author{
Americus Perez ${ }^{1}$, Susumu Umino ${ }^{1}$, Graciano P. Yumul Jr. $^{2}$, and Osamu Ishizuka ${ }^{3,4}$ \\ ${ }^{1}$ Division of Natural System, Graduate School of Natural Science and Technology, \\ Kanazawa University, Kakuma-machi, Kanazawa, 920-1192, Japan \\ ${ }^{2}$ Apex Mining Company Inc., Ortigas Center, Pasig City, 1605, Philippines \\ ${ }^{3}$ Research Institute of Earthquake and Volcano Geology, Geological Survey of Japan, AIST, \\ Tsukuba Central 7, 1-1-1 Higashi, Tsukuba, Ibaraki 305-8567, Japan \\ ${ }^{4}$ Research and Development Center for Ocean Drilling Science, JAMSTEC, 2-15 Natsushima, \\ Yokosuka, Kanagawa 237-0061, Japan
}

Correspondence: Americus Perez (americus.perez@gmail.com, adperez@stu.kanazawa-u.ac.jp)

Received: 25 December 2017 - Discussion started: 31 January 2018

Revised: 7 May 2018 - Accepted: 12 May 2018 - Published: 5 June 2018

\begin{abstract}
A key component of subduction initiation rock suites is boninite, a high-magnesium andesite that is uniquely predominant in western Pacific forearc terranes and in select Tethyan ophiolites such as Oman and Troodos. We report, for the first time, the discovery of low-calcium, high-silica boninite in the middle Eocene Zambales ophiolite (Luzon Island, Philippines). Olivine-orthopyroxene microphyric high-silica boninite, olivine-clinopyroxene-phyric low-silica boninite and boninitic basalt occur as lapilli fall deposits and pillow lava flows in the upper volcanic unit of the juvenile arc section (Barlo locality, Acoje Block) of the Zambales ophiolite. This upper volcanic unit overlies a lower volcanic unit consisting of basaltic andesite, andesite to dacitic lavas and explosive eruptive material (subaqueous pahoehoe and lobate sheet flows, agglutinate and spatter deposits) forming a low-silica boninite series. The overall volcanic stratigraphy of the extrusive sequence at Barlo resembles holes U1439 and U1442 drilled by IODP Expedition 352 in the Izu-Ogasawara (Bonin) trench slope. The presence of depleted proto-arc basalts in the Coto Block (45 Ma) (Geary et al., 1989), boninite and boninite series volcanics in Barlo (Acoje Block (44 Ma)) and simultaneous and post-boninite moderate-Fe arc tholeiites in Sual and Subic areas of the Acoje Block (44-43 Ma) indicate that the observed subduction initiation stratigraphy in the Izu-Ogasawara-Mariana forearc is also present in the Zambales ophiolite. Paleolat-
\end{abstract}

itudes derived from tilt-corrected sites in the Acoje Block place the juvenile arc of northern Zambales ophiolite in the western margin of the Philippine Sea plate. In this scenario, the origin of Philippine Sea plate boninites (IBM and Zambales) would be in a doubly vergent subduction initiation setting.

\section{Introduction}

As the surface manifestation of a convecting mantle, subduction zones play a fundamental role in material transfer from the surface to the deep interior and vice versa. Early in Earth's history, the transition from a stagnant lid regime to the present mode dominated by plate forces necessitates subduction initiation. Numerical models show that plate tectonics or mantle overturn in terrestrial planets can be triggered by narrow plumes impinging on weakened crust inducing gravitational instability and slab descent (Crameri and Tackley, 2016; Gerya et al., 2015). Internally driven mechanisms such as plume-induced subduction initiation (Whattam and Stern, 2015), however, are fundamentally different from end-member models of Cenozoic subduction initiation which rely on preexisting zones of weakness such as fracture zones and transform faults or require lithospheric collapse (Stern, 
2004). How subduction begins in the oceanic domain is one fundamental issue yet to be fully deciphered, thus it is regarded as a high priority scientific target (Challenge No. 11) of the International Ocean Discovery Program (IODP) for 2013 to 2023. Understanding this volcanic and tectonic process is hampered by its transient nature, with few examples in the geologic record with the exception of submarine active and paleo-forearcs and terrestrial supra-subduction ophiolites.

In testing subduction initiation models, the Izu-Ogasawara (Bonin)-Mariana (IBM) forearc region remains as one the most appropriate localities; this is due to its temporally distinct volcanic record of oceanic accretion and juvenile arc magmatism immediately following the onset of subduction. After the subduction of the Pacific Plate beneath the Philippine Sea plate commenced at $52 \mathrm{Ma}$, magmatism progressed from 52 to $48 \mathrm{Ma}$ mid-ocean ridge basalt (MORB)-like proto-arc basalts (or forearc basalts) to 48$44 \mathrm{Ma}$ boninite and boninite-series volcanics, followed by 45-35 Ma arc tholeiites and calc-alkaline lavas (Ishizuka et al., 2011; Kanayama et al., 2012; Reagan et al., 2010). The widespread occurrence of subduction initiation rock suites along the eastern margin of the Philippine Sea plate is summarized in Fig. 1a. Basalts of similar composition and age range to proto-arc basalts dredged along the Mariana and Bonin trench slopes were found at IODP Expedition 351 Site U1438 in the Amami Sankaku Basin (Arculus et al., 2015; Ishizuka et al., 2018). This indicates that the Oligocene Kyushu-Palau Ridge (KPR) intra-oceanic arc is built upon an igneous basement that formed part of the earliest seafloor spreading event related to subduction initiation. The subsequent late Oligocene opening of the Shikoku-Parece Vela Basin resulted in its present configuration with Site U1438 in the back-arc side of KPR. Based on dredging and dive observations in the forearc trench slope, proto-arc basalts are found at deeper depths relative to boninites which occur upslope and subaerially at Chichijima (type locality) and Mukojima island groups (Ishizuka et al., 2011; Kanayama et al., 2012; Umino and Nakano, 2007). The hypothesis that protoarc basalt lies stratigraphically below boninite has been suggested by IODP Expedition 352 based on four sites drilled in the trench-side slope of the Bonin Ridge (Reagan et al., 2015, 2017). Both spontaneous and induced initiation have been replicated in numerical models of incipient subduction at the IBM. Earlier models with imposed plate velocities generally focused on initiation across a preexisting weak zone, and combined with melting models could reproduce the observed proto-arc basalt-boninite stratigraphy (Hall et al., 2003; Leng et al., 2012). Subsequently, spontaneous subduction initiation has been shown to be plausible with compositional density contrast being provided by the thickened middle crust of relic Cretaceous arc terranes (Leng and Gurnis, 2015). So far, neither spontaneous nor induced initiation models can uniquely explain the subduction initiation that produced the IBM forearc and the mechanism remains elusive (Keenan and Encarnación, 2016).

Here an alternative approach to exploring subduction initiation processes in the western Pacific region is presented. Following Stern et al. (2012), this study focuses on the middle Eocene Zambales ophiolite in the Philippines as it offers a $\sim 3200 \mathrm{~km}^{2}$ exposure of Eocene supra-subduction oceanic lithosphere. Most of the Jurassic to Cretaceous ophiolites that form basement complexes in the eastern Philippines are increasingly recognized as complementary features to Cretaceous terranes in the northern Philippine Sea plate (e.g., Amami Plateau, Daito Ridge) possibly sharing a common history as the overriding plate prior to initiation of subduction (Billedo et al., 1996; David et al., 1997; Deschamps and Lallemand, 2002; Lallemand, 2016). Therefore, juxtaposed Eocene ophiolites are potential targets to investigate subduction initiation as a plate-scale process. Regional tectonic reconstructions predict the interaction of a pre-Eocene ocean basin located east of Eurasia and the western margin of the Philippine Sea plate (Wu et al., 2016). Coincidentally, aside from the IBM forearc region, the Dasol-Barlo locality in northern Zambales ophiolite is where middle Eocene boninitic rocks are also reported (Evans et al., 1991; Florendo and Hawkins, 1992; Hawkins and Evans, 1983). The significance of Zambales ophiolite as an analogue of the IBM forearc has been recognized since the early 1990s (Pearce et al., 1992) yet this connection remains unexplored. Motivated by how the ophiolite concept progressed through studies of the IBM forearc, we present field, petrologic and geochemical characterization of a juvenile arc section in northern Zambales ophiolite to evaluate subduction initiation and boninite petrogenesis in a regional geodynamic context.

\section{Geologic background}

Located in western Luzon, the structurally coherent Zambales ophiolite is a representative supra-subduction ophiolite of the western Pacific and the largest in the Philippines (Fig. 1b). The ophiolite spans the entire Zambales mountain range from 16 to $14.7^{\circ} \mathrm{N}$ where it partly underlies stratovolcanoes of the Luzon Arc, including Mt. Pinatubo. It consists of three fault-bound massifs, namely Masinloc, Cabangan and San Antonio, which each preserve complete ophiolite internal stratigraphy. The ophiolite is flanked by the Central Valley basin (CVB) to the east and West Luzon basin to the west. Late Eocene to late Miocene Aksitero and Moriones formations of the CVB record the transition from a hemipelagic, deep marine setting to a shallower environment dominated by ophiolite-derived sedimentation signaling the uplift of the ophiolite; while sedimentary sequences west of the ophiolite, the Cabaluan and Sta. Cruz formations, indicate that terrane docking and large-scale uplift had transpired by the Pliocene (Karig et al., 1986; Schweller et al., 1984). Sporadic chert slivers with late Jurassic-early Creta- 


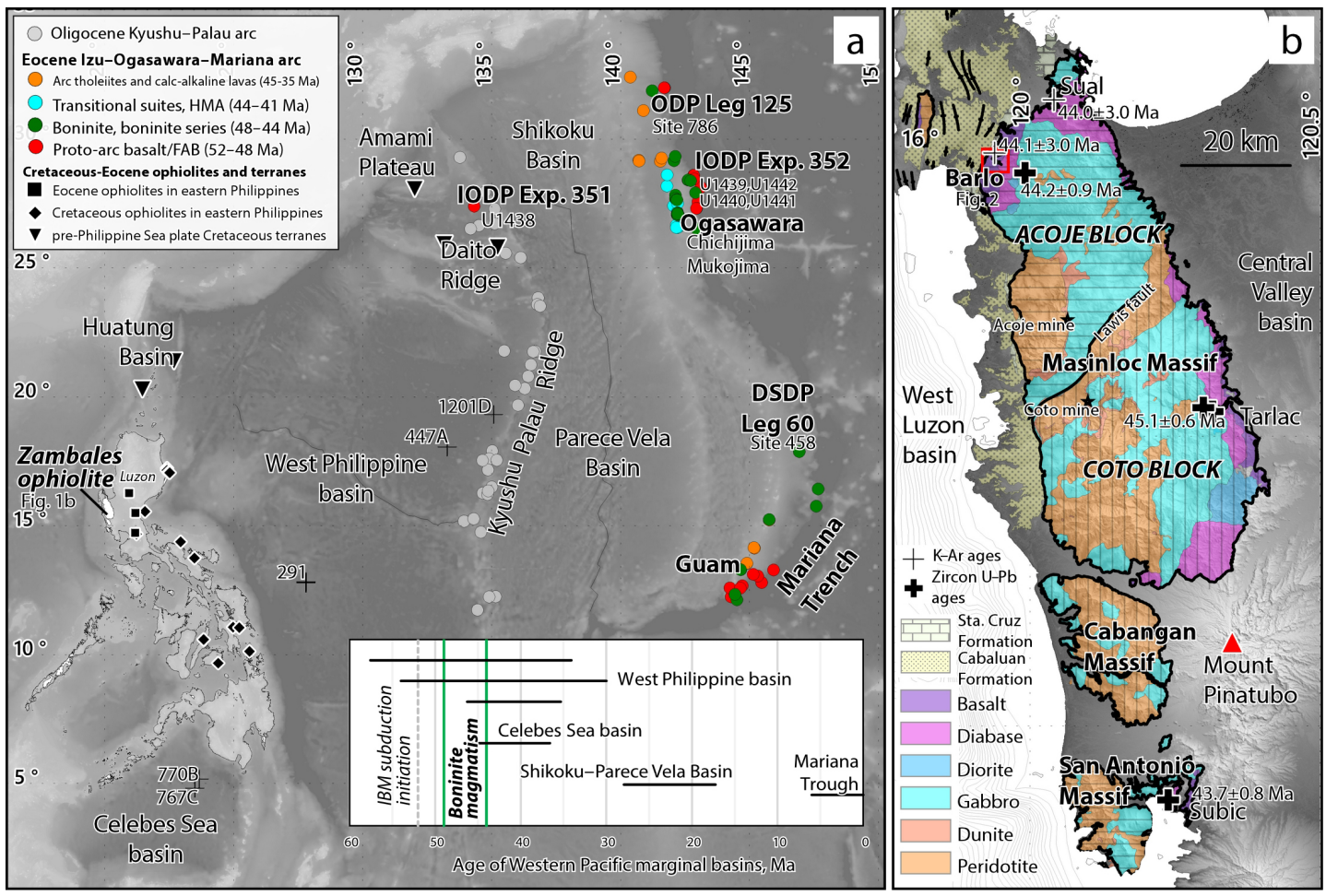

Figure 1. (a) Distribution of subduction initiation rock suites in the Philippine Sea plate and spreading histories of associated marginal basins (Deschamps and Lallemand, 2002; Pearce et al., 1992; Reagan et al., 2017). (b) Regional geological map of the Zambales ophiolite after Yumul et al. (1990) with whole-rock K-Ar and zircon U-Pb ages from Fuller et al. (1989) and Encarnacion et al. (1993). The 44-43 Ma Acoje Block consists of the northern Masinloc Massif and the southernmost San Antonio Massif. The enclosed region (red box) is the Barlo extrusive section mapped in this study.

ceous radiolarian fauna are found in the westernmost margin of the ophiolite (Hawkins and Evans, 1983; Karig et al., 1986; Queaño et al., 2017b). Similar Mesozoic cherts associated with disrupted ophiolitic fragments in northern Luzon highlight the existence of a shear zone (west Luzon shear zone) west of the ophiolite (Encarnación, 2004; Karig, 1983; Queaño et al., 2017a).

Petrologic, geochemical and isotopic studies reveal that the Zambales ophiolite represents two distinct mantle-crust sequences: the 45.1 Ma Coto Block with affinity transitional to mid-ocean ridge basalt (MORB) and island arc tholeiite (IAT), and the 44.2-43.7 Ma Acoje Block with island arc characteristics (Encarnación et al., 1999, 1993; Geary et al., 1989; Hawkins and Evans, 1983; Yumul, 1990). The existence of a NNE-SSW trending structural boundary previously characterized by Hawkins and Evans (1983) as a left-lateral fault between Acoje and Coto blocks within the Masinloc Massif is supported by gravity and magnetic data with anomaly contrasts which extend at depth (Salapare et al., 2015). Although the juvenile arc character of Acoje Block and the supra-subduction origin of Zambales ophiolite are clear, the crustal nature and tectonic environment of Acoje and Coto blocks remain unresolved. The Acoje Block as defined by Yumul et al. (1990) consists of the northern Masinloc Massif and the San Antonio Massif while the Coto Block consists of the southern Masinloc Massif and the Cabangan Massif (Fig. 1b). The present disposition of the Acoje Block is postulated to be the result of the southward translation of San Antonio Massif with respect to northern Masinloc Massif (Yumul et al., 1998). Crustal thickness estimates, based on SW-NE transects of the northern Masinloc Massif, are up to $9.5 \mathrm{~km}$ for the mantle section and $7 \mathrm{~km}$ for the lower crustal section. The fertile to moderately depleted Acoje mantle section is comprised of harzburgite and lherzolite with spinel $\mathrm{Cr} \#[\mathrm{Cr} /(\mathrm{Cr}+\mathrm{Al})]$ ranging from 0.18 to 0.56 , generally increasing towards the mantle-crust transition zone (Evans and Hawkins, 1989; Yumul, 1990). Harzburgites from the uppermost mantle section are strongly depleted in light and middle rare earth elements (LREEs and MREEs) with equilibration temperature and oxygen fugacity estimates of $730^{\circ} \mathrm{C}$ and $1.9 \Delta \log \left(f \mathrm{O}_{2}\right)$ units above the FMQ buffer, respectively (Tamayo, 2001). From the residual mantle section, the mantle-crust transition zone passes through interlayered ultramafic cumulates and dunite to layered cumulate gabbronorite. The Acoje transition zone hosts podiform chromite deposits $(\mathrm{Cr} \#=0.71-$ 0.77 ) and $\mathrm{Ni}-\mathrm{Cu}$ sulfides, both of which are PGE-bearing (Bacuta et al., 1990). Refractory transition zone dunites, 
characterized by spinel $\mathrm{Cr} \#$ greater than 0.6 , are interpreted to be of cumulate origin (Abrajano et al., 1989). The Acoje Block lower crustal section is dominated by cumulate gabbronorites with an olivine-clinopyroxene-orthopyroxeneplagioclase crystallization sequence. Coexisting plagioclase and clinopyroxene in gabbronorite are calcic (anorthite content $[\mathrm{Ca} /(\mathrm{Ca}+\mathrm{Na}+\mathrm{K})]=89-94)$ and magnesian $(\mathrm{Mg \#}$ $[\mathrm{Mg} /(\mathrm{Mg}+\mathrm{Fe})]=0.80-0.87)$. In addition to petrological criteria discussed above, the arc affinity of Acoje Block has been demonstrated using immobile element-based geochemical fingerprinting of volcanic and hypabyssal rocks, as well as constituent clinopyroxene (Yumul, 1996). On a regional scale, the ophiolite appears to have a domal structure with a north-south trending axis. The volcanic section of Acoje Block in the northern Masinloc Massif dips northwest and is unconformably overlain by middle to late Miocene sedimentary sequences.

\section{Volcanic geology}

Based on observations around the Barlo massive sulfide mine, two volcanic units with distinct lithofacies are distinguished in the Acoje Block extrusive sequence: a dominantly pyroclastic lower basaltic andesite-andesite unit overlain by an upper boninite unit with minor boninitic basalts. Here and in the succeeding sections, we use the term boninite as per the recommended IUGS criterion (Le Maitre, 2002). Pillow lavas that qualify as boninite based on $\mathrm{MgO}$ and $\mathrm{TiO}_{2}$ contents but with less than $52 \mathrm{wt} \% \mathrm{SiO}_{2}$ are classified as boninitic basalts, equivalent to the "basaltic boninite" of Reagan et al. (2015). Structural measurements of bedding planes in 136 locations constrain the gross structure of the crustal sequence, consisting of a NE-SW trending doubly plunging anticline forming a dome structure and NW-plunging anticline (Fig. 2). Estimated thickness of the upper unit and lower volcanic units are 680 and $520 \mathrm{~m}$, respectively.

South of Barlo mine, boninite dike swarms with conjugate intrusive directions change into a succession of submarine explosive volcanic deposits. In order of ascending stratigraphic level, the lower basaltic andesite-andesite unit consists of tuff breccia with block-sized pyroclasts, subaqueous pahoehoe lava flows with ropy wrinkles and stretched vesicles on lobe crust (Umino et al., 2002, 2000) (Fig. 3f), moderately welded agglutinate, welded scoria and spatter deposits marginal to a NW-SE trending fissure vent, and an uppermost subaqueous fallout deposit of glassy lapilli tuff (Fig. 3e). In places, tuff breccia is cut by NE-dipping boninite dikes. The dominant occurrence of flat pahoehoe lobes suggest the preexistence of subhorizontal topography (Umino et al., 2002). The volcanic facies recognized in the upper section of the lower volcanic unit (agglutinate, scoria and spatter deposits surrounding fissure vent) are characteristic of intermittent submarine Strombolian to Hawaiian-style fountaining (Head and Wilson, 2003).
NW-dipping boninite tuff breccia and pillow lavas of the upper unit (Fig. 3b) overlie hyaloclastite, spatter deposits and pillow lavas (Fig. 3c) of the lower basaltic andesiteandesite unit at an exposure north of Mt. Sol. A sill directly above lower unit pillow lavas has a whole-rock K-Ar age of $44.1 \pm 3.0 \mathrm{Ma}$ (Fuller et al., 1989). Pillow lavas of the upper and lower unit show distinct morphological features based on measurements of vertical $(V)$ and horizontal $(H)$ axes following the method of Walker (1992). Pillow lavas of the lower unit are marked by lower aspect ratios $(n=92$, median $H=0.53 \mathrm{~m}$, median $V=0.34 \mathrm{~m}$ ) compared to boninitic basalts of the upper unit which are elongate $(n=15$, median $H=0.74 \mathrm{~m}$, median $V=0.32 \mathrm{~m}$ ). Southeast of Barlo mine, NE-dipping pillow lavas of the upper unit are overlain by middle-late Eocene radiolarian-bearing claystone (Schweller et al., 1984). Further southwest in a synclinal area with upright structures preserved, a $\sim 30 \mathrm{~m}$ high boninite pillow volcano is recognized (Fig. 3d). It consists of flattened flow lobes in the summit with pillow lavas dipping downslope along its flanks. This volcanic construct is one of several discrete boninitic volcanic edifices rising above the lower unit. Elsewhere, these pillow lavas are cut by SW-dipping dikes with glassy margins and overlain by glassy boninite lapilli tuff fall deposit (Fig. 3a).

\section{Sampling and analytical methods}

A total of 152 samples were collected during the 2016 mapping campaign. For this study, a subset of 44 samples located along NW-SE transects of the Acoje Block volcanic sequence at Barlo were selected for whole-rock geochemical analyses and screened through visual and microscopic assessment of secondary alteration. Location of samples is shown in the geologic map in Fig. 2. Rock slabs were cut to remove altered surfaces. Initially, slabs were crushed coarsely to manually separate low temperature secondary minerals such as quartz and calcite. The coarse crushing step was followed by rinsing with deionized water and drying in an oven at $110^{\circ} \mathrm{C}$ for at least $12 \mathrm{~h}$. An iron mortar and an agate mill were used for fine crushing and grinding, respectively. Ignition loss is taken as the normalized weight lost after ignition of ground rock powder at $900^{\circ} \mathrm{C}$ for $4 \mathrm{~h}$. Major element compositions were determined by X-ray fluorescence (XRF) spectrometry using a PANanalytical Axios spectrometer at the Geological Survey of Japan/National Institute of Advanced Industrial Science and Technology. Glass beads were fused using a Tokyo Kagaku bead sampler (TK$4500)$ at a $1: 10$ dilution ratio as mixtures of $0.5 \mathrm{~g}( \pm 0.0002)$ rock powder and $5 \mathrm{~g}( \pm 0.001)$ lithium tetraborate alkali flux $\left(\mathrm{Li}_{2} \mathrm{~B}_{4} \mathrm{O}_{7}\right.$, Merck Spectromelt A10). Precision, measured as percent relative standard deviation (\%RSD), was better than $2 \%$ based on repeated measurements of JB-2, BIR-1 and BHVO-2; accuracy was also better than $2 \%$. Trace element (REE, V, Cr, Ni, Li, Be, Rb, Sr, Y, Zr, Nb, Cs, Ba, Hf, Ta, 


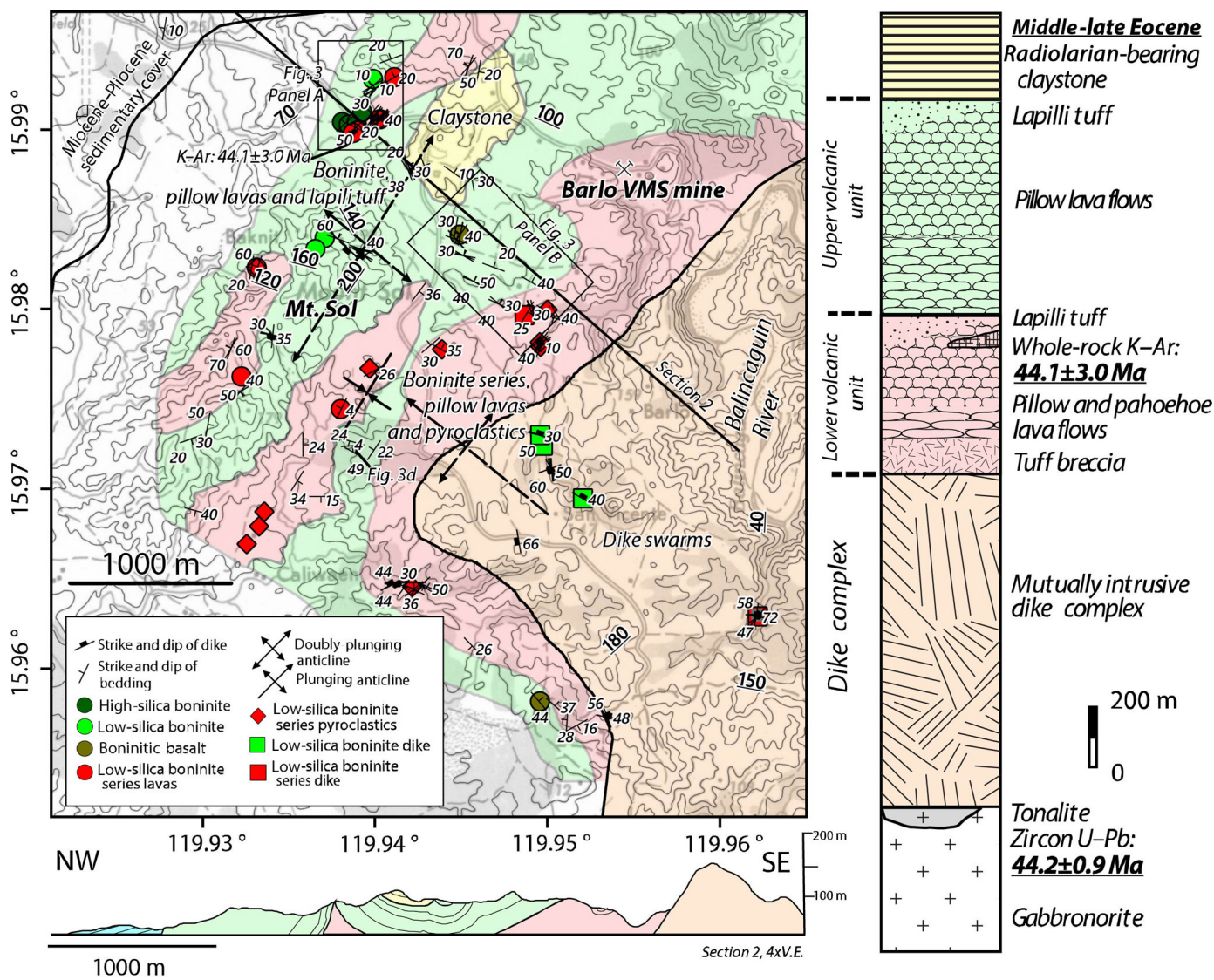

Figure 2. Geological map of Barlo and its environs. Closed symbols are samples with whole-rock geochemical data. Enclosed areas (panels A and B) are shown in Fig. 3. Geologic cross-section is given along a NW-SE section line. Geologic column shows stratigraphic relationships and estimated thickness of the upper and lower volcanic unit. Biostratigraphic, whole-rock K-Ar and zircon U-Pb ages are from Schweller et al. (1984), Fuller et al. (1989) and Encarnacion et al. (1993).

$\mathrm{Pb}$, Th and $\mathrm{U}$ ) concentrations were determined by inductively coupled plasma mass spectrometry (ICP-MS) using an Agilent 7900 instrument also located at the Geological Survey of Japan. Samples were digested for at least $48 \mathrm{~h}$ on a hotplate using screw top Teflon beakers with a mixture of HF and HNO3 at a $5: 1$ ratio. Dissolution procedures were performed in a Class 1000 clean laboratory. Twelve international standards (BIR-1, BRR-1, JB-2, JB-3, JA-1, JGb-1, JA-2, BCR1, AGV-1, JB-1a, BHVO-2 and BE-N-1) were used to construct calibration lines. Standard JB-2 and JB-3 solutions at similar dilution levels were used as external standards. Reproducibility is better than $2 \%$ for REEs and better than $3 \%$ for the rest of the trace elements except for Ta $(6.5 \%)$ and $\mathrm{Be}(3.6 \%)$. Mean percent error is generally within 5 to $10 \%$ relative to the preferred values of Jochum et al. (2016) and Dulski (2001).

Major element compositions of constituent mineral phases were determined with a JEOL-8800R electron microprobe at Kanazawa University using a $3 \mu \mathrm{m}$ probe diameter, $20 \mathrm{nA}$ probe current and $20 \mathrm{kV}$ accelerating voltage. Natural (Kurose olivine and clinopyroxene) and synthetic mineral standards were used for calibration and data were corrected using the ZAF method.

\section{Results}

Representative mineral chemistry data are listed in Table S1 in the Supplement. Results of whole-rock major and trace element analyses are given in Table S2 with total Fe represented as $\mathrm{Fe}_{2} \mathrm{O}_{3}$. In succeeding discussions, all samples are normalized to $100 \%$ volatile free with total $\mathrm{Fe}$ recalculated as $\mathrm{FeO}^{*}$ to enable comparison with compiled datasets.

\subsection{Textures and phase chemistry}

Zambales high-silica boninite (as defined in Sect. 5.2) is mostly aphyric and consists of subhedral olivine microphenocrysts $\left(\mathrm{Mg} \#\left[\mathrm{Mg} /\left(\mathrm{Mg}+\mathrm{Fe}^{2+}\right)\right]=0.88-0.91\right)$, abundant elongate enstatite microphenocrysts $(\mathrm{Mg} \#=0.86$ $0.89, \mathrm{Wo}_{2.6-4.9} \mathrm{En}_{82-86}$ ) with augite (with or without pigeonite overgrowth) $\left(\mathrm{Mg \#}=0.67-0.84, \mathrm{Wo}_{31-44} \mathrm{En}_{34-57}\right)$, and chromian spinel $(\mathrm{Cr} \#[\mathrm{Cr} /(\mathrm{Cr}+\mathrm{Al})]=0.69-0.84$, 

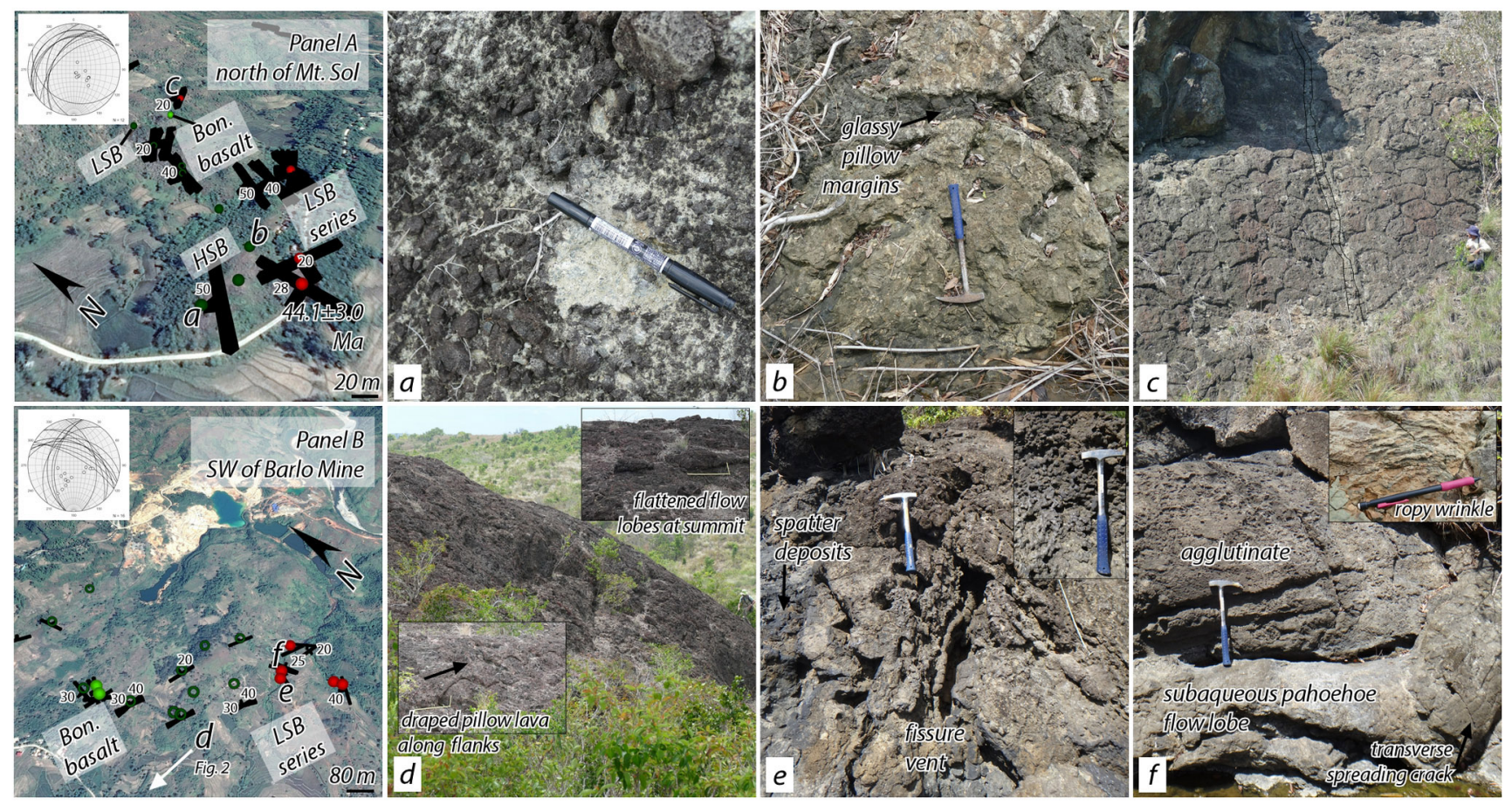

Figure 3. Representative outcrops showing distinct volcanic facies and stratigraphic relationship of the upper boninite unit and lower basaltic andesite-andesite unit. (a) High-Si boninite lapilli tuff. (b) High-Si boninite pillow lava with fresh glassy margins. (c) Basaltic andesite pillow lavas cut by boninite dike. (d) Boninite pillow volcano. (e) Fissure vent with fluidal, flattened basaltic andesite-andesite spatter deposits and lapilli tuff. (f) Basaltic andesite pahoehoe flow with ropy wrinkles (inset) and transverse spreading cracks on lobe crust indicating flow direction. Rock hammer for scale $(0.42 \mathrm{~m})$. Orientation poles of bedding planes (dip azimuth) are shown in lower hemisphere stereographic projection (Vollmer, 2015). Bedding plane orientations in Google Earth (Digital Globe, CNES/Astrium) images, viewed from southeast direction, are visualized using the S2K macro (Blenkinsop, 2012).

$\mathrm{Mg \#}=0.53-0.69)$ set in a glassy groundmass with feathery quench clinopyroxene (Fig. 4a-b). This assemblage corresponds to "Type II boninite" of Umino (1986) in samples described from the type locality at Chichijima Island, Ogasawara (Bonin) Archipelago in southern Japan. Unlike low$\mathrm{Ca}$, high-silica boninites from Ogasawara, clinoenstatite has not been identified so far. Comparative mineral chemistry of Zambales and Ogasawara boninite is shown in Fig. 5. Olivine, orthopyroxene and spinel compositions of Zambales and Ogasawara boninite are almost identical except for a lim-

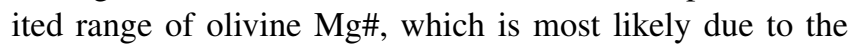
small number of samples analyzed (two for olivine and four for spinel), and lower spinel Cr\# in Zambales boninite (Taylor et al., 1994; Umino, 1986; Yajima and Fujimaki, 2001). $\mathrm{NiO}$ contents of olivine range from 0.18 to $0.41 \mathrm{wt} \%$ and plot on fractionation trends from the mantle olivine array. Subhedral olivine microphenocrysts in high-silica boninite (ZM2100A) are zoned with magnesian cores. The range of spinel $\mathrm{Cr} \#$ of Zambales boninite overlap with Acoje podiform chromitites and transition zone dunites. Enstatite microphenocrysts with sieve texture and reverse zoning are recognized together with embayed quartz xenocrysts (Fig. 4c-e). Reversely zoned enstatite has oscillatory-zoned magnesian rims $(\mathrm{Mg} \#=0.86-0.87)$ with resorbed and dissolved cores $(\mathrm{Mg} \#=0.68-0.77)$. Similar xenocrystic quartz and sievetextured enstatite have also been noted in Ogasawara boninite (Watanabe and Kuroda, 2000). Glassy olivine-phyric and olivine-clinopyroxene-phyric low-silica boninite varieties are also present (Fig. 4f). Hypocrystalline boninite pillow lavas consist of olivine, usually altered and replaced by chlorite and carbonate minerals, subhedral clinopyroxene phenocrysts, elongate orthopyroxene and plagioclase microphenocrysts.

Highly phyric boninitic basalt has a phenocryst assemblage of olivine replaced by calcite, zeolite and clay minerals, euhedral to subhedral augite $(\mathrm{Mg} \#=0.82-0.90$, $\left.\mathrm{Wo}_{41-43} \mathrm{En}_{48-53}\right)$ with oscillatory and sector zoning, and rare corroded enstatite $\left(\mathrm{Mg} \#=0.85-0.88, \mathrm{Wo}_{3} \mathrm{En}_{82-84}\right)$ with reverse zoning. Chromian spinel $(\mathrm{Cr} \#=0.62-0.71)$ occurs near phenocryst margins and as inclusions in olivine. A peculiar zoning relationship of augite and enstatite demonstrates that some pyroxenes are xenocrysts in nature. Groundmass consists of less than $0.3 \mathrm{~mm}$ long plagioclase microlites with swallow-tail terminations, spherulitic clinopyroxene and altered interstitial glass totally replaced by clay minerals. Acicular zeolite occurs as vesicle fillings. We note that such tex- 


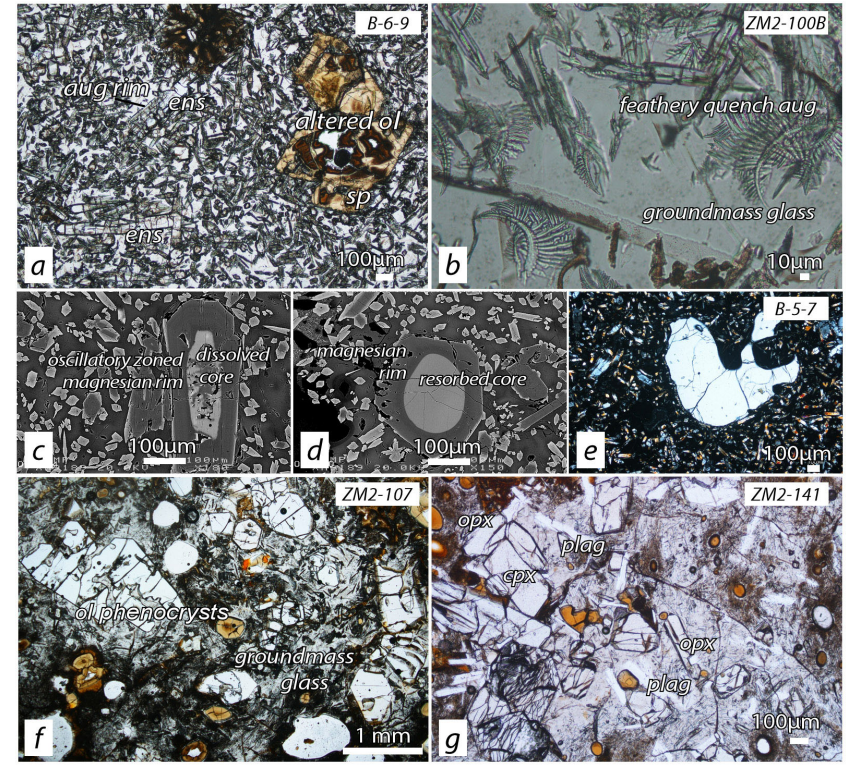

Figure 4. Microphotographs showing the textures of Zambales boninite and boninite-series volcanics. (a) High-silica boninite (HSB) with altered olivine and abundant elongate enstatite microphenocrysts with augite rims (plane polarized light). (b) Characteristic feathery clinopyroxene in groundmass glass, HSB (plane polarized light). (c) Oscillatory zoning in magnesian rim of enstatite xenocryst with dissolved core, HSB (BSE). (d) Reverse zoning in enstatite xenocryst with resorbed core, HSB (BSE). (e) Embayed quartz xenocryst, HSB (crossed polars). (f) Low-silica boninite (LSB) with fresh olivine phenocrysts in glassy groundmass (plane polarized light). (g) Plagioclase, orthopyroxene and clinopyroxene microphenocrysts in LSB-series basaltic andesite tuff breccia matrix (plane polarized light).

tures have been described in samples reported as boninite by Evans et al. (1991).

Lower-unit basaltic andesite and andesite pillows and lapilli tuff are marked by the presence of abundant plagioclase laths as glomerocrysts and sparse cpx with or without opx microphenocrysts with two-pyroxene intergrowths in a glassy groundmass with plagioclase microlites and magnetite (Fig. 4g).

\subsection{Whole-rock geochemistry}

The Acoje Block extrusive section at Barlo is predominantly composed of basaltic andesite and andesite. Loss on ignition (LOI) values are generally between 4 and $7 \mathrm{wt} \%$ and total alkalis are less than $3 \mathrm{wt} \%$ (Table S2). Cs, Rb, K, Li, Ba and Mn contents in some dikes and pillow lavas, especially those collected nearest to the massive sulfide mine, are highly scattered and plot away from general fractionation trends shown by the majority of samples. The rest of the samples show variations in the major element and trace element compositions consistent with fractional crystallization; thus, the geochemical characteristics are deemed as primary. Pillow lava, tuff breccia and lapilli tuff of the upper volcanic unit and dikes from the uppermost section of the dike-sill complex are primitive with $>8 \mathrm{wt} \% \mathrm{MgO}$ and $<0.5 \mathrm{wt} \% \mathrm{TiO}_{2}$, satisfying the IUGS criteria for boninite (Le Maitre, 2002). Following the classification of Kanayama et al. (2013) and Reagan et al. (2015) both high-silica (HSB) and low-silica (LSB) boninite subtypes are recognized (Fig. 6). This compositional division is consistent with petrographic observations, with HSB having olivine with orthopyroxene microphenocrysts and LSB with olivine or olivine with clinopyroxene phenocrysts. Boninitic samples previously described at Barlo are actually from the dike section and lower section of the upper unit and with sampling having being limited to Balincaguin River and the periphery of Barlo VMS mine (Evans et al., 1991; Hawkins and Evans, 1983; Tamayo, 2001; Yumul, 1990). Besides the low-silica boninite and boninitic basalt samples from previous studies with altered equivalents having more than $3.5 \mathrm{wt} \% \mathrm{Na}_{2} \mathrm{O}+\mathrm{K}_{2} \mathrm{O}, 3-5 \mathrm{wt} \% \mathrm{LOI}$ and possibly up to $4 \mathrm{wt} \% \mathrm{SiO}_{2}$ enrichment, this is the first report of pristine high-silica boninite in the Zambales ophiolite. Boninite from Zambales $(n=14)$ have $\mathrm{CaO} / \mathrm{Al}_{2} \mathrm{O}_{3}$ ratios less than 0.76 , mostly within $0.63-0.71$ with $\mathrm{FeO}^{*} / \mathrm{MgO}$ ratios $<1$ (Mg\# values from 63 to 73 ). $\mathrm{Ni}$ and $\mathrm{Cr}$ contents are high, ranging from 72 to 292 and 145 to $727 \mu \mathrm{g} \mathrm{g}^{-1}$, respectively. Boninitic basalts $(n=3)$ are primitive as well with 12.4 $13.6 \mathrm{wt} \% \mathrm{MgO}$ and $712-1113 \mu \mathrm{g} \mathrm{g}^{-1} \mathrm{Cr}$.

Pillow lava and lapilli tuff of the lower volcanic unit and dikes from the deeper section of the dike-sill complex are andesitic in composition with 55.5-63.5 wt \% $\mathrm{SiO}_{2}, 2.4$ $7.1 \mathrm{wt} \% \mathrm{MgO}$ and $0.31-0.47 \mathrm{wt} \% \mathrm{TiO}_{2}$ (Fig. 6). These andesites $(n=26)$ are magnesian with $\mathrm{Mg \#}$ mostly between 0.47 and $0.54, \mathrm{CaO} / \mathrm{Al}_{2} \mathrm{O}_{3}$ ratios $<0.63, \mathrm{FeO}^{*} / \mathrm{MgO}$ ratios >1.16. and $\mathrm{Ni}$ and $\mathrm{Cr}$ contents are also low at 8-58 and 3-47 $\mu \mathrm{g} \mathrm{g}^{-1}$, respectively. $\mathrm{MgO}$ and $\mathrm{SiO}_{2}$ compositions of lower unit volcanics and corresponding dikes lie above the island arc basalt (B)-basaltic andesite (BA)-andesite (A) dacite (D) discriminant line of Pearce and Robinson (2010) and follow a curvilinear fractionation trend from low-silica boninite; thus, are recognized here as forming a low-silica boninite differentiation series (Fig. 6). Dacitic pillow lavas represent the differentiated end of the LSB series. A gap between andesitic boninite-series volcanics with $<60 \mathrm{wt} \%$ $\mathrm{SiO}_{2}$ and dacite $(62-63 \mathrm{wt} \%)$ is present. A single dike (B-47 d4) that cross cuts the LSB-series dikes is the only sample with $>0.5 \mathrm{wt} \% \mathrm{TiO}_{2}$. Although the pervasive clay alteration of samples from the Barlo massive sulfide mine hinders the direct characterization of the host rocks, the massive sulfide deposit is most likely hosted by the lower volcanic unit and possibly up to the lowermost section of the upper unit based on stratigraphic relationships and comparison of field and core descriptions (Paringit, 1977). The occurrence of massive sulfide-bearing horizons at Barlo is also consistent with massive sulfide mineralization in Oman, Troodos and Bonin Ridge which occur either below or within the boninitic volcanic section (Ishizuka et al., 2014; Umino et al., 2009). 

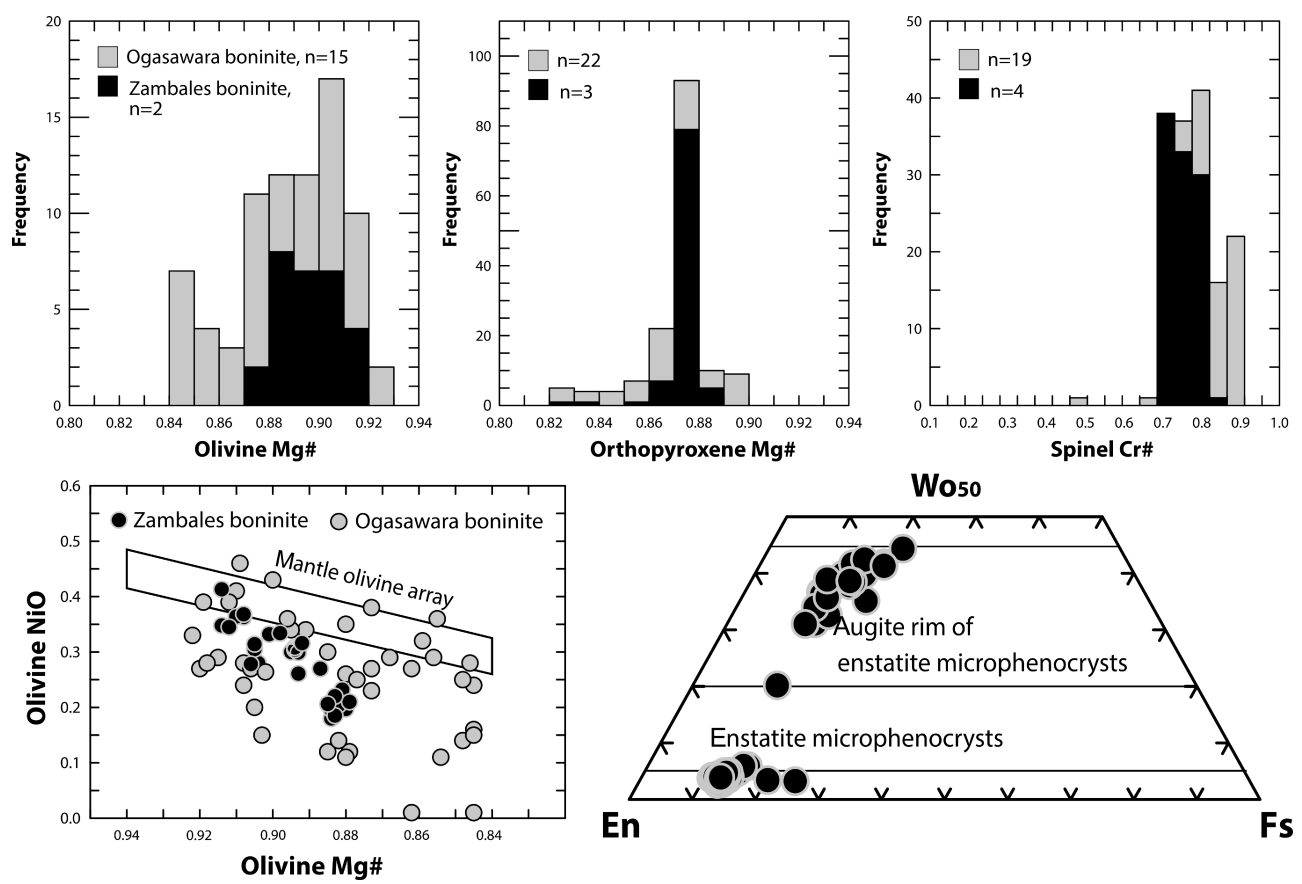

Figure 5. Comparative mineral chemistry of constituent phases (olivine, orthopyroxene, clinopyroxene and spinel) in Zambales and Ogasawara boninites. Mantle olivine array is from Takahashi (1986).

Compositions of Zambales boninite and boninite series volcanics are marked by low incompatible trace element abundances relative to MORB (Fig. 7). Extended trace element patterns arranged after Pearce and Parkinson (1993) show the dominance of slab-derived components with notable enrichment in fluid-mobile elements $(\mathrm{Cs}, \mathrm{Rb}, \mathrm{Ba}, \mathrm{U}$, $\mathrm{K}, \mathrm{Pb}, \mathrm{Sr}, \mathrm{Li}, \mathrm{Na}$ ) and depletion of high field strength elements $(\mathrm{Nb}, \mathrm{Ta})$. Hf shows a positive anomaly relative to Sm while Ti shows a negative anomaly relative to Y. In contrast with samples from Ogasawara that exhibit characteristic U-shaped chondrite-normalized rare earth element (REE) patterns, Zambales boninite and boninite-series volcanics exhibit spoon-shaped REE patterns with heavy REEs (HREE) at 5-15 times the chondrite values and weak negative $\mathrm{Eu}$ anomaly $\left(\mathrm{Eu} / \mathrm{Eu}^{*}=0.9\right)$. Boninitic basalts are more depleted in middle and heavy REEs with just three to five times the chondrite values. Excluding moderately altered samples, chondrite normalized $\mathrm{La} / \mathrm{Ce}\left([\mathrm{La} / \mathrm{Ce}]_{N}\right)$ ratios of Zambales and Ogasawara boninite are both less than one. The range of $[\mathrm{Sm} / \mathrm{Yb}]_{N}$ ratios, as measure of middle REE depletion relative to heavy REE, however, are distinct at 0.060.09 for Zambales and 0.02-0.05 for Ogasawara. The effect of fractionation in Zambales boninite samples is shown as increasing trace element abundances relative to a glassy olivine-phyric LSB (ZM2-107) with $12.4 \mathrm{wt} \% \mathrm{MgO}$. The evolved dacitic samples do not differ significantly with just twice the normalized REE abundances of the most primitive sample. Trace element pattern of a single dike (B-47 d4) with greater than $0.5 \mathrm{wt} \% \mathrm{TiO}_{2}$ is visibly different with muted fluid-mobile element enrichment without a negative Ti anomaly, and smooth, concave downward LREE depletion (Fig. 7).

The volcanic sequence at Barlo, based on observed local stratigraphic relationships, is LSB series volcanics-boninitic basalt-LSB-HSB from base to top. (Fig. 3). This volcanic stratigraphy is remarkably similar to holes U1439 and U1442 of IODP Exp. 352. Both the Barlo extrusive section and holes U1439 and U1442 are marked by an abundance of LSB relative to HSB (Reagan et al., 2015). In contrast, the onshore boninite sequence at Ogasawara is dominated by $48-46 \mathrm{Ma}$ HSB and HSB series volcanics interbedded with minor LSB (Maruberiwan Formation), which are overlain by $45 \mathrm{Ma}$ LSB and calc-alkaline andesite-dacite (Mikazukiyama Formation) (Kanayama et al., 2012; Taylor et al., 1994; Umino, 1986). Several dikes in the Subic crustal section in the southern San Antonio massif have compositions like Barlo boninitic basalts (Yumul et al., 2000), albeit their petrographic characteristics have not been described. This raises the possibility that boninite is present in other volcanic sections of the Acoje Block as well. The rest of the volcanic sections of the Zambales ophiolite (Coto volcanic section in Tarlac, Sual dikes north of Barlo, and Subic dikes and pillow lavas in the south) are dominated by basalts and basaltic andesites with greater than $0.5 \mathrm{wt} \% \mathrm{TiO}_{2}$ which can be classified as moderate-Fe tholeiites (Fig. S1 in the Supplement). The tholeiite dike (B-47 d4) that cross cuts low-silica boninite dikes in the deeper dike swarm section at Barlo is similar in composition and correlatable with $44.0 \pm 3.0$ Ma dikes in 

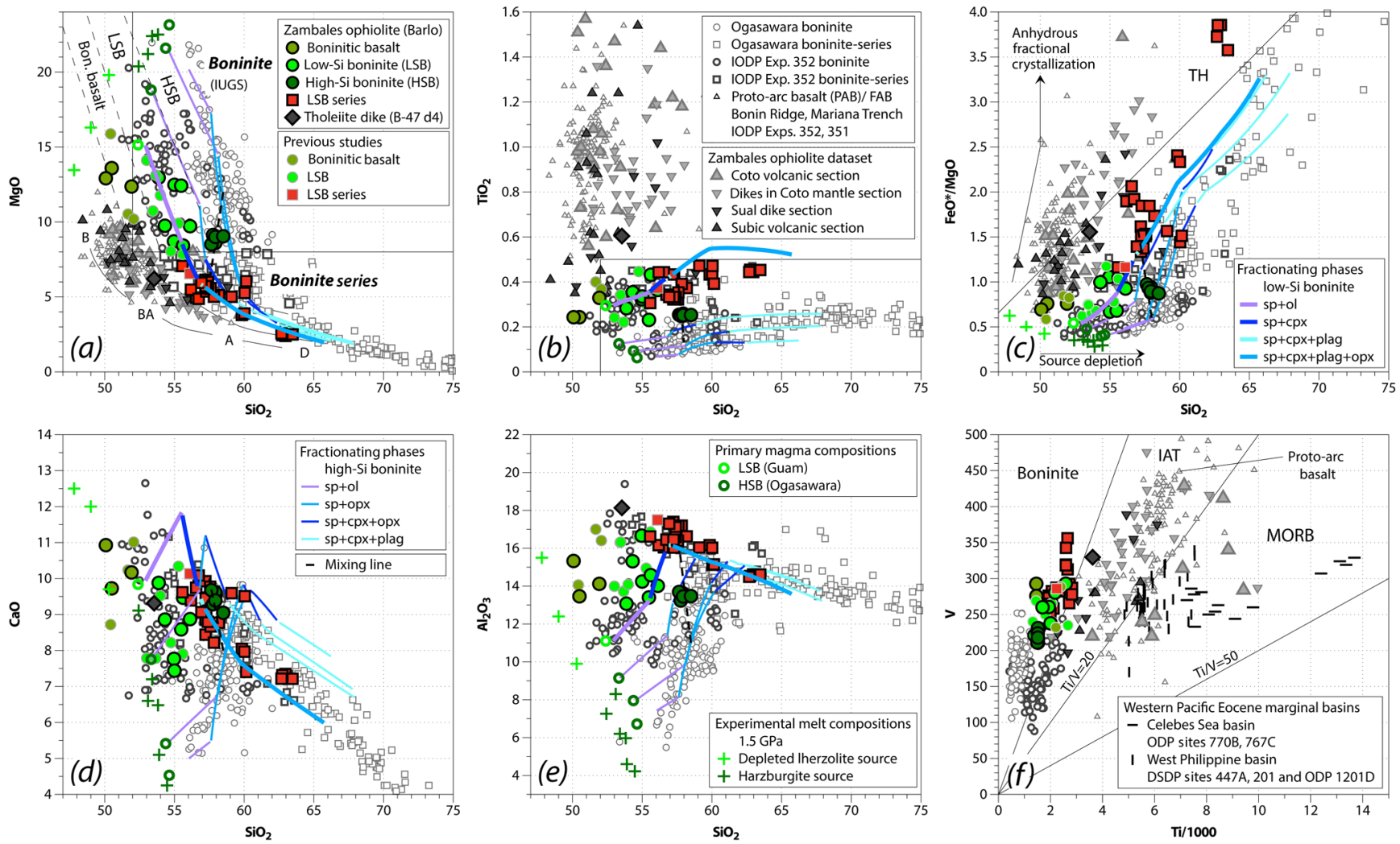

Figure 6. (a-e) $\mathrm{MgO}, \mathrm{TiO}_{2}, \mathrm{FeO}^{*} / \mathrm{MgO}, \mathrm{CaO}, \mathrm{Al}_{2} \mathrm{O}_{3}$ vs. $\mathrm{SiO}_{2}$ variation diagrams showing the distinct parental magma compositions and modeled fractional crystallization paths of high- and low-silica boninites and boninite-series volcanics. Fractional crystallization paths are modeled using rhyoliteMELTS v.1.2.0 (Ghiorso and Gualda, 2015) at $1 \mathrm{~kb}$ pressure and initial $\mathrm{fO}_{2}$ of FMQ +1 . The designated primary boninite magmas given by Umino et al. (2018) are used as parental compositions with an initial $\mathrm{H}_{2} \mathrm{O}$ content of 1 wt $\%$. Models were run at temperature range of $1500-980^{\circ} \mathrm{C}$. Modified boninite classification after Kanayama et al. (2013) and Reagan et al. (2015). Dividing lines between boninite and basalt-andesite-dacite-rhyolite (BADR) series are from Pearce and Robinson (2010). (f) Ti-V systematics (Shervais, 1982) of IBM and Zambales subduction initiation rock suites is also shown.

the Sual crustal section located NE of Barlo, suggesting that tholeiites are coeval or slightly younger than the Barlo extrusive section.

\section{Discussion}

\subsection{Low-pressure fractionation and magma mixing}

Early experimental studies of primitive boninite produced andesitic primary liquids and led to the initial characterization of boninite as a primary magma (Kuroda et al., 1978). Subsequent detailed petrologic analyses resulted in the recognition of the importance of low-pressure fractionation and magma mixing processes to account for the compositional variation of boninite and boninite series volcanics (Dobson et al., 2006; Taylor et al., 1994; Umino, 1986). Meijer (1980) introduced the concept of the boninite series to describe cogenetic bronzite andesite, dacite and rhyolite formed through the differentiation of boninite, analogous to tholeiitic and calc-alkaline magma series. Figure 6 shows oxide vs.
$\mathrm{SiO}_{2}$ variation diagrams of Zambales boninite and boninite series volcanics. Also shown are boninite and boninite series volcanics from Ogasawara (Kanayama et al., 2012; Nagaishi, 2008; Taylor et al., 1994; Umino and Nakano, 2007; Yajima and Fujimaki, 2001) and holes U1439 and U1442 of IODP Expedition 352 (Haugen, 2017; Reagan et al., 2015). $\mathrm{MgO}, \mathrm{TiO}_{2}, \mathrm{CaO}$ and $\mathrm{Al}_{2} \mathrm{O}_{3}$ contents of HSB and LSB form subparallel trends suggesting distinct parental magma compositions and fractionation paths. Parental HSB is characterized by higher $\mathrm{MgO}$, and lower $\mathrm{TiO}_{2}, \mathrm{Al}_{2} \mathrm{O}_{3}$ and $\mathrm{CaO}$ at a given $\mathrm{SiO}_{2}$ than LSB. HSB is marked by the abundance of orthopyroxene and, in some localities, the presence of clinoenstatite. Umino (1986) describes the crystallization sequence at Chichijima as chromian spinel, olivine, clinoenstatite, enstatite and augite. The HSB differentiation series is best exemplified by samples from Ogasawara and Site 786, ODP Leg 125 (Arculus et al., 1992). Boninite from other notable western Pacific localities such as the Mariana Trench (Bloomer and Hawkins, 1987; Dietrich et al., 1978), Cape Vogel, Papua New Guinea (Jenner, 1981; König et al., 2010), 

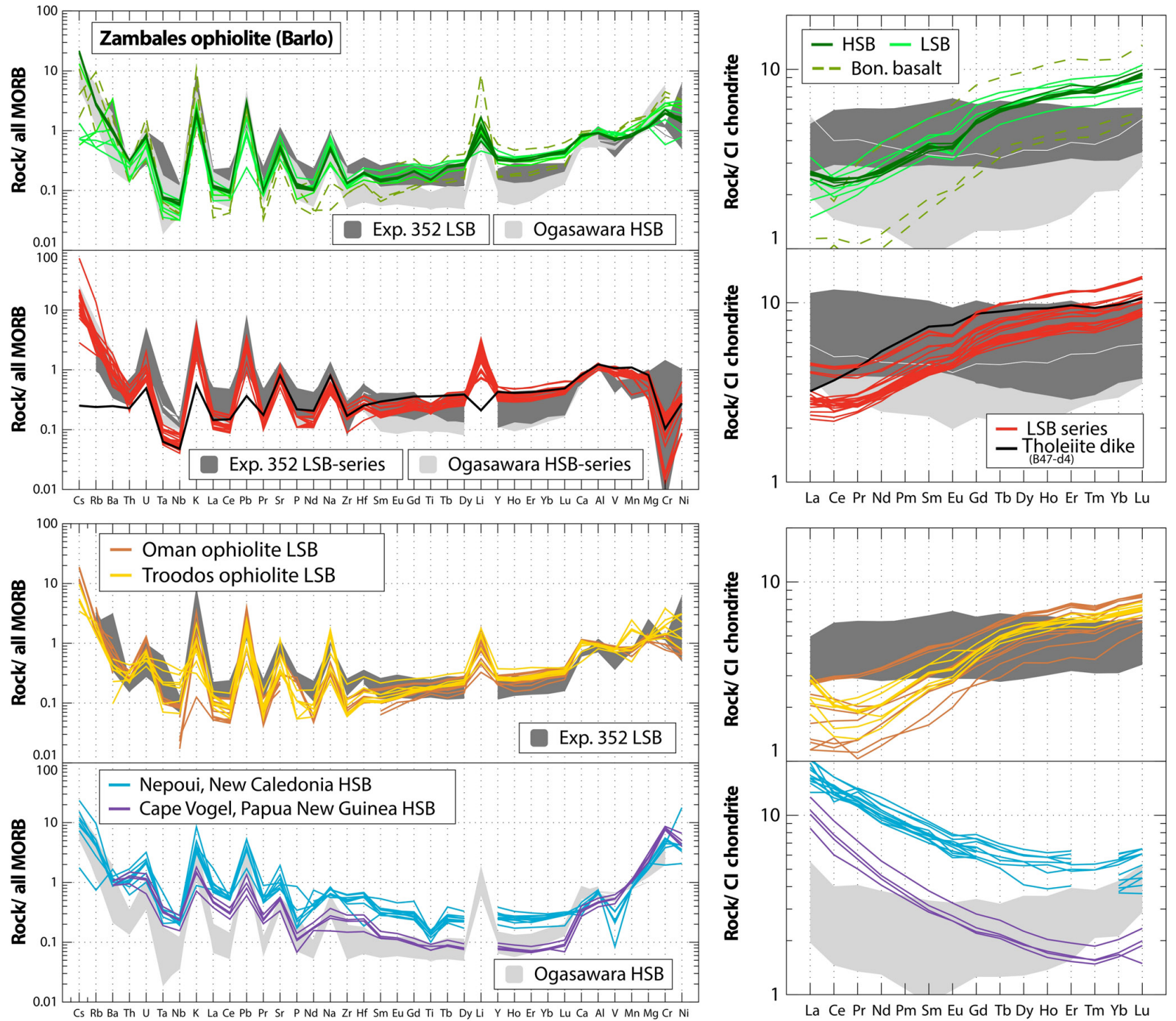

Figure 7. Extended MORB and chondrite normalized trace element patterns. Normalizing values are from Barrat et al. (2012) and Gale et al. (2013).

Nepoui, New Caledonia (Cameron, 1989; Cluzel et al., 2016) and Hahajima Seamount (Li et al., 2013) are all high-silica sub type. Zambales HSB show limited compositional variation with most of the samples collected in an area north of Mt. Sol, possibly from a single volcanic edifice. Conversely, the LSB crystallization sequence is controlled by olivine and clinopyroxene fractionation (Kostopoulos and Murton, 1992; Natland, 1982). The LSB differentiation series is typified by suites from northern Zambales, holes U1439 and U1442 of Expedition 352 and Hole 458, ODP Leg 60 (Meijer, 1982; Sharaskin, 1982). Other LSB and LSB series localities include Facpi Formation in Guam (Reagan and Meijer, 1984), Tonga Trench (Falloon et al., 2007; Falloon and Crawford, 1991), Troodos ophiolite (Cameron, 1985; König et al., 2008; Osozawa et al., 2012; Pearce and Robinson, 2010) and Oman ophiolite (Ishikawa et al., 2002; Kusano et al., 2017, 2014; Nagaishi, 2008).
Using spinel-hosted melt inclusions reported by Umino et al. (2018) as parental magma compositions, isobaric fractional crystallization paths of residual liquids at $+1 \Delta \log (\mathrm{FMQ})$ are modeled using rhyoliteMELTS v.1.2.0 (Ghiorso and Gualda, 2015). The compositions of primary spinel-hosted boninitic melt inclusions from Ogasawara (2.1-3.4 wt $\left.\% \mathrm{H}_{2} \mathrm{O}\right)$ and Guam $\left(3.8 \mathrm{wt} \% \mathrm{H}_{2} \mathrm{O}\right)$ are in accord with experimental glasses formed by melting synthetic Troodos harzburgite and depleted Tinaquillo lherzolite at $1.5 \mathrm{GPa}$ (Falloon and Danyushevsky, 2000) (Fig. 6). The range of whole-rock HSB compositions can be reproduced by low pressure (1-2 kb) fractional crystallization of parental Ogasawara HSB magmas at lower water content (1 wt \%). The $\mathrm{TiO}_{2}$ and $\mathrm{CaO}$ contents of Zambales HSB are in the upper end of Ogasawara HSB compositions and can alternatively be produced by fractionation from a parental composition straddling the HSB and LSB boundary of Reagan et 
al. (2015). Given a primary LSB magma composition identical to a spinel-hosted melt inclusion from Guam, low pressure $(1-2 \mathrm{~kb})$ fractional crystallization at lower water content $(1 \mathrm{wt} \%)$ can likewise account for the major element variation of Zambales LSB and LSB series volcanics. The modeled early crystallization of cpx relative to opx and the onset of plagioclase crystallization following cpx at $\sim 57 \mathrm{wt} \%$ $\mathrm{SiO}_{2}$ is reflected in the modal compositions of Zambales LSB and LSB-series volcanics (Fig. 4). The occurrence of differentiated LSB series volcanics at the base of the volcanic pile suggests that initial LSB magmas underwent protracted crystal fractionation in magma chambers at depth; the influx of primitive HSB perturbed sub-volcanic magma chambers and likely induced magma mixing. The presence of reversely zoned enstatite microphenocrysts in Zambales HSB, attest to high-level magma mixing between an olivine with orthopyroxene saturated HSB magma and a preexisting LSB series andesitic magma. Zambales HSB deviate slightly from the modeled Ogasawara HSB fractionation paths and lie on a mixing line with potential HSB and LSB-series end-member components having $\mathrm{SiO}_{2}$ contents that do not vary significantly at 58 and $57 \mathrm{wt} \%$, respectively.

The markedly divergent fractionation paths followed by boninite and boninite series volcanics from Barlo and basalts from various volcanic sections of the Zambales ophiolite are shown in the $\mathrm{MgO}, \mathrm{TiO}_{2}$ and $\mathrm{FeO}^{*} / \mathrm{MgO}$ vs $\mathrm{SiO}_{2}$ variation diagrams (Fig. 6). Zambales LSB and LSB series volcanics follow fractionation paths of hydrous primitive arc magmas (Grove et al., 2012). Moderate-Fe tholeiitic basalts and basaltic andesites from the rest of the volcanic sections of Zambales ophiolite (Evans et al., 1991; Geary et al., 1989; Hawkins and Evans, 1983; Tamayo, 2001; Yumul, 1990) and proto-arc basalts from the Izu-Ogasawara-Mariana forearc (Arculus et al., 2015; Ishizuka et al., 2011; Reagan et al., 2010, 2015) exhibit large $\mathrm{FeO}^{*} / \mathrm{MgO}$ ratio variation at a restricted $\mathrm{SiO}_{2}$ interval and define a slope steeper than the discriminant line of Miyashiro (1974).

\subsection{Slab contributions to a less depleted mantle source}

Although there is a general consensus on boninite petrogenesis (Bedard, 1999; Crawford et al., 1989; Pearce et al., 1992), namely that it involves the shallow flux melting of refractory peridotite more depleted than MORB sources, the requisite sub-arc conditions ideal for boninite generation span a range that may involve heterogeneous mantle wedge sources (depleted lherzolite to harzburgite) and the addition of diverse slab-derived components (Cluzel et al., 2016; Kusano et al., 2017; Umino et al., 2015, 2018). We highlight the peculiar trace element characteristics of Zambales boninite; geochemical modeling will be presented elsewhere. Figure 7 shows MORB and chondrite-normalized trace element patterns of Zambales boninite and boninite-series volcanics together with boninite suites from Ogasawara, holes U1439 and U1442 of IODP Expedition 352, Troodos and Oman ophiolites, Nepoui (New Caledonia) and Cape Vogel (Papua New Guinea). Boninite from Zambales, Oman and Troodos ophiolites all show spoon-shaped chondrite normalized REE patterns with heavy REEs that are five to nine times chondrite values. Based on HREE abundances and spinel Cr\#, Zambales boninite is derived from a mantle source that is less depleted than Ogasawara boninite (Fig. 7).

Superimposed on the depleted character of boninite are slab-derived components whose nature can be explored using normalized trace element diagrams and trace element ratios with varying compatibilities. The magnitude of hydrous fluid mobile element enrichment in boninite from Ogasawara, Zambales, Oman and Troodos ophiolites are comparable. LREE enrichment is most prominent in Nepoui and Cape Vogel boninites. All boninite suites except for Nepoui and Cape Vogel have elevated $\mathrm{Ba} / \mathrm{Th}$ ratios (Fig. 8a). Ba is strongly partitioned into aqueous fluids relative to $\mathrm{Th}$, thus is a good proxy for the addition of subduction components released at shallow depths - sz1, Ba-only component of Pearce et al. (2005) (Keppler, 2017; Ribeiro et al., 2015). Increasing $\mathrm{Ba} / \mathrm{Th}$ ratio is mirrored by increasing $\mathrm{Sr} / \mathrm{Nd}$ ratio for Zambales, Oman and Troodos boninite (Fig. 8b). Ogasawara, Cape Vogel and Nepoui follow a vertical Th / Yb vector (Fig. 8b) towards sediments - "component 1" of Elliott (2003). We interpret this decoupling as an indicator of increasing contributions from a deep subduction component that is usually characterized as either sediment melt and/or siliceous fluid (Pearce et al., 2005). Zambales boninite and boninite-series volcanics have $\mathrm{U} / \mathrm{Th}$ ratios $(0.62-$ $0.77)$ much higher than Cape Vogel boninites (0.20-0.29). A high $\mathrm{U} / \mathrm{Th}$ ratio is associated with saline and oxidizing fluids, while a low $\mathrm{U} / \mathrm{Th}$ ratio points to the transport of silicarich fluids to source (Keppler, 2017). Zambales and Cape Vogel boninites both have a uniform $\mathrm{La} / \mathrm{Th}$ ratio of 0.2 . In the La / Th vs. Sm / La diagram of Plank (2005) (not shown), Zambales, Oman and Troodos boninites lie on a mixing line between sediments with a Th / La ratio of 0.30 and 0.35 and a mantle source more refractory than MORB with a Sm / La ratio of 1.75. Ogasawara, Cape Vogel and Nepoui boninites may lie on the mixing line between sediments with a Th / La ratio of 0.1 and 0.2 and a highly depleted mantle source with a $\mathrm{Sm} / \mathrm{La}$ ratio greater than 2. An alternative explanation is that the low $\mathrm{Sm} / \mathrm{La}$ ratios of Ogasawara, Cape Vogel and Nepoui boninites dominantly reflect LREE enrichment which masks the mixing relationship. The shared characteristics of Zambales, Oman, and Troodos boninites are further exemplified by subchondritic bulk Earth $\mathrm{Nb} / \mathrm{Ta}$ ratios with low $\mathrm{Zr} / \mathrm{Hf}$ and $\mathrm{Zr} / \mathrm{Sm}$ ratios $(<30)$ characteristic of depleted mantle (Münker et al., 2003; Weyer et al., 2003; Zanetti et al., 2006) (Fig. 8c). The high $\mathrm{Zr} / \mathrm{Sm}$ ratios (>40) of Ogasawara, Cape Vogel and Nepoui boninites have been ascribed to the presence of residual amphibole in the slab (Cluzel et al., 2016; König et al., 2010; Pearce et al., 1992). In summary, trace element ratios show that aqueous fluids are the dominant slab components in Zambales boni- 

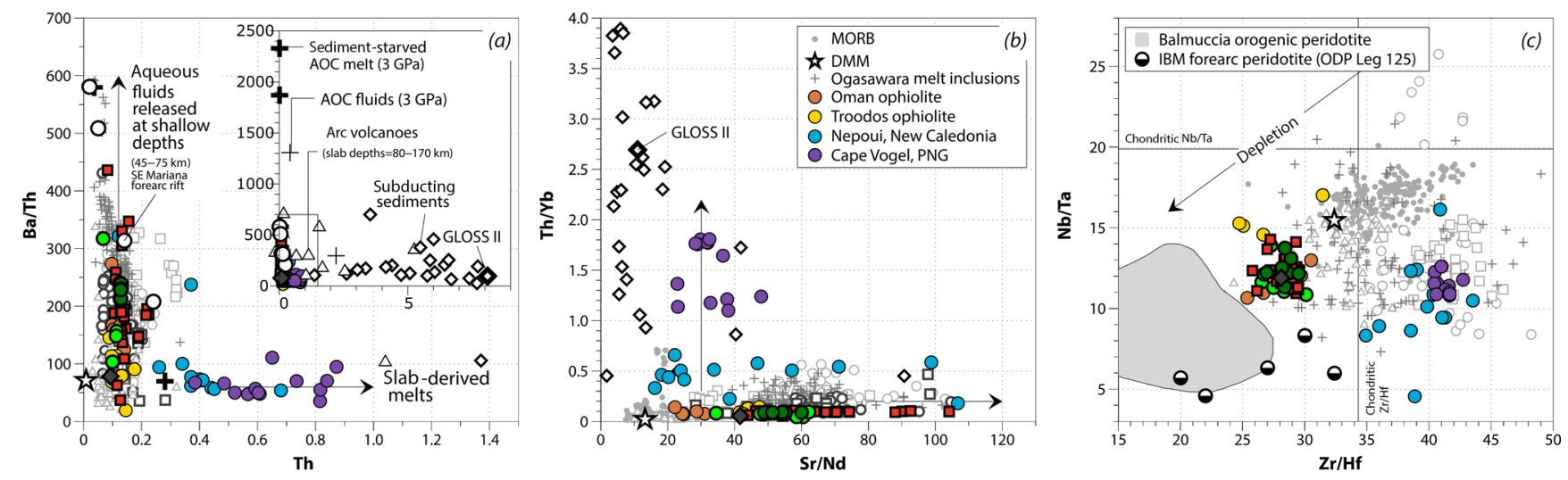

Figure 8. Trace element ratios discriminating the nature of slab-derived components in boninite and boninite-series volcanics. Zambales, Oman and Troodos boninites have distinct LILE and HFSE enrichments compared to Ogasawara, Cape Vogel and Nepoui. Data sources: Ogasawara spinel-hosted boninitic melt inclusions (Umino et al., 2018), altered oceanic crust (AOC) fluids, melts and sediments (Carter et al., 2015), aqueous fluids released at shallow depths (Ribeiro et al., 2015) and subducting sediments and GLOSS II (Plank, 2014). Chondritic bulk Earth Nb / Ta and Zr / Hf ratios are from Münker et al. (2003). DMM and MORB compositions are from Jenner and O’Neill (2012) and Workman and Hart (2005), respectively. Symbols are the same as those in Fig. 6 except those shown in the diagram.

nite and boninite series volcanics. This is corroborated by the enriched $\mathrm{Pb}$ and $\mathrm{Sr}$ isotopic compositions of the Acoje Block's uppermost crustal differentiates and cumulate ultramafic samples that do not show an inverse relationship with $\mathrm{Nd}$ isotopic compositions (Encarnación et al., 1999).

\subsection{Subduction initiation origin of the Zambales ophiolite}

The 45 Ma crustal section of the Coto Block has a composition transitional to mid-ocean ridge basalt (MORB) and island arc tholeiite (IAT). On the basis of immobile elementbased trace element discrimination diagrams, Coto Block dikes and lavas from Tarlac are robustly characterized as distinct from Mariana Trough back-arc basin basalts (Geary et al., 1989). Decreasing REEs, $\mathrm{TiO}_{2}, \mathrm{Zr}$ and $\mathrm{Y}$ in Coto volcanics, dikes in the Coto mantle section to Acoje volcanics document the progressive depletion of the mantle source in Zambales mantle wedge (Yumul, 1990). Succeeding zircon $\mathrm{U}-\mathrm{Pb}$ geochronology established the 1-2 Myr age difference between Coto and Acoje blocks (Encarnación et al., 1993). Thus, combined geochemical and age constraints preclude a back-arc basin origin for Coto Block as forwarded by Hawkins and Evans (1983), and are more compatible with a proto-forearc setting as originally suggested by Geary et al. (1989). Coto Block volcanics $(n=9)$ have variable $\mathrm{Ti} / \mathrm{V}$ ratios, mostly between 20 and 26 (Fig. 6f). Recognizing the small sample size, this range is higher than protoarc basalts (PAB) and overlaps with MORB (Fig. S2a); this suggests a less oxidized source than IBM PAB (Brounce et al., 2015; Hickey-Vargas et al., 2018; Mallmann and O'Neill, 2009). The corresponding $\mathrm{Ti}_{8}$ and $\mathrm{Si}_{8}$ values of the Coto Block are comparable with proto-arc basalts from the Bonin Ridge, Mariana Trench slope, Hole U1430 of IODP Exp. 351 and Hole 1440 of IODP Exp. 352 (Arculus et al., 2015; Ishizuka et al., 2011; Reagan et al., 2010, 2015) (Fig. 9). $\mathrm{Si}_{8}$ and $\mathrm{Ti}_{8}$ values of Coto Block basalts are also distinct from Celebes Sea basin and West Philippine basin MORB (Pearce et al., 2005; Savov et al., 2006; Serri et al., 1991; Spadea et al., 1996; Zakariadze, 1981). In addition, the primitive mantle-normalized fluid immobile trace element abundances of Coto Block volcanics are also exceptionally low and more depleted compared to MORB (Hickey-Vargas et al., 2018) and Celebes Sea basin basalts (Fig. S2b). From field observations, oceanic accretion can be inferred from the Coto crustal section based on a well-developed sheeted dike complex, in contrast to the mutually intrusive dikes of the Acoje crustal section. With the recognition of boninite and boninite-series volcanics (Barlo), and moderate-Fe arc tholeiites (Barlo-Sual, Subic) in the crustal section of Acoje Block, it is apparent that subduction initiation chemostratigraphy (Ishizuka et al., 2011; Whattam and Stern, 2011) is present in the Zambales ophiolite as well. Although stratigraphic relationships of individual volcanic sections may be obfuscated by emplacement-related tectonic deformation, by considering available age constraints, the crustal sections of the Zambales ophiolite represent proto-arc accretion and juvenile arc sections supplied by separate magma plumbing systems as observed at IODP Exp. 352 sites (Reagan et al., 2015).

\subsection{Doubly vergent subduction initiation}

Previous attempts to ascertain the provenance of Zambales ophiolite focused on its characterization as a marginal basin and thus linked it to the surrounding Eocene marginal basins such as the Celebes Sea basin and Molucca Sea basin. In the most comprehensive petrological and geochemical study of 


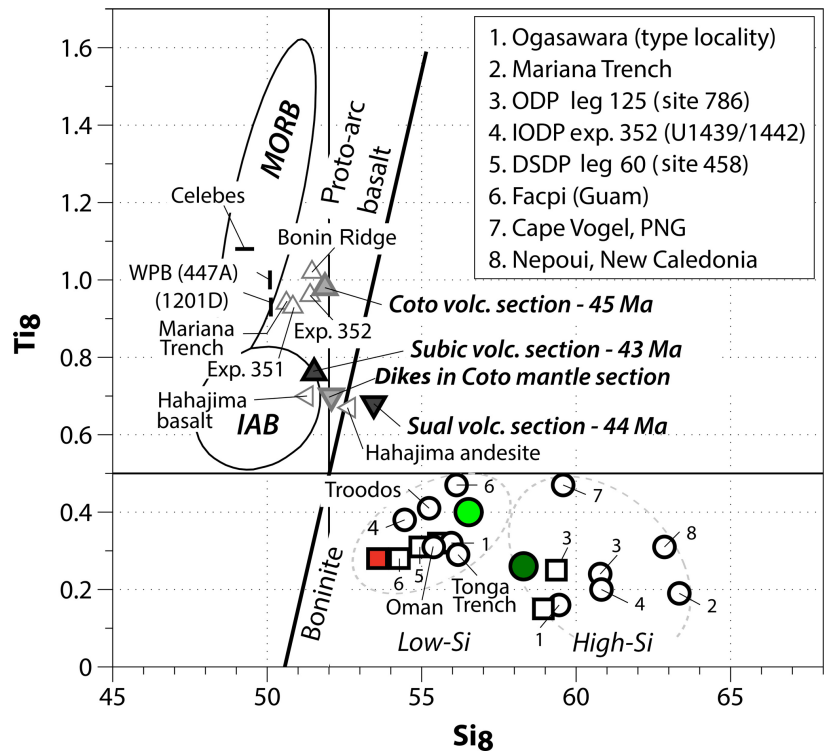

Figure 9. The 8 wt $\% \mathrm{MgO}$-normalized $\mathrm{SiO}_{2}\left(\mathrm{Si}_{8}\right)$ and $\mathrm{TiO}_{2}\left(\mathrm{Ti}_{8}\right)$ values of the crustal sections of Zambales ophiolite and IBM forearc showing temporal evolution from proto-arc basalt, boninite to arc tholeiite associated with subduction initiation. Also shown are $\mathrm{Si}_{8}-\mathrm{Ti}_{8}$ values of other notable boninite localities (Oman, Troodos, Tonga Trench). MORB and IAB fields are from Pearce and Robinson (2010). Data sources are given in the text. Symbols are the same as in Fig. 6 except those shown in the diagram.

Philippine ophiolites, Tamayo et al. (2004) noted the strong subduction geochemical imprint of Zambales ophiolite and placed it as a marginal basin between the Celebes Sea basin and the western margin of the Philippine Sea plate. The difficulty in reconstructing the Paleogene tectonic configuration of the southeast Asian region, specifically the spreading history of the oceanic domain east of Sundaland and west of the Philippine Sea plate, stems from the fact that this region has been fully consumed along convergent margins east of southeastern Eurasia (Zahirovic et al., 2014). This gap was addressed by Wu et al. (2016) through the novel use of structural unfolding of subducted slabs imaged by seismic tomography. In their preferred model (model 1b), unfolding of subducted slabs beneath southern Eurasia reveals that the Philippine Sea plate was bordered by Cretaceous oceanic crust (the East Asian Sea) in its western margin. Paleomagnetic data derived from sites in the Philippine Sea plate show northward translation concomitant with clockwise rotation (Hall et al., 1995; Richter and Ali, 2015; Yamazaki et al., 2010) (Fig. 10a). Eocene to Miocene sites from Luzon indicate similar northward migration; thus, the island can be regarded as the western promontory of the Philippine Sea plate (Queano et al., 2007). The subequatorial position of Luzon during the middle Eocene is further supported by paleomagnetic data from pillow lavas forming the basement of Luzon Central Cordillera (K-Ar age: $45.49 \pm 2.27 \mathrm{Ma})$ that yield a paleo- latitude of $6.3 \pm 3^{\circ} \mathrm{S}$ (Queaño et al., 2009; Sajona, 1995). East of Luzon and forming the greater part of Philippine Sea plate, the West Philippine basin (WPB) is characterized as a back-arc basin formed between opposing subduction zones (Deschamps and Lallemand, 2002). Pre-Eocene subduction south of WPB possibly generated the Mesozoic arc terranes in the Philippine Sea plate including Amami Plateau and Daito Ridge as well as the Cretaceous ophiolites in the eastern Philippines (Lallemand, 2016). Initiation of a long-lived subduction east of the WPB produced the Izu-Ogasawara (Bonin)-Mariana (IBM) forearc above a west-dipping subduction zone (Ishizuka et al., 2011). It is in this context that we re-evaluate the origin of Zambales ophiolite.

Tilt-corrected inclination data from sites in the $44 \mathrm{Ma}$ Acoje Block equate to equatorial paleolatitudes (Fuller et al., 1991). Adopting southerly paleolatitudes in consonance with the modeled Luzon translation history of Wu et al. (2016), we make a case for the subduction initiation origin of the Zambales ophiolite in the leading edge of the northwestwardmoving, clockwise-rotating Philippine Sea plate. In this scenario, the origin of Philippine Sea plate boninites (IBM and Zambales) would be in a doubly vergent subduction initiation setting (Fig. 10b). In contrast with IBM, incipient subduction which produced Zambales ophiolite proto-arc basalts, boninites and arc tholeiites within $3 \mathrm{Ma}$ is rather short-lived and alludes to rapid emplacement. The timing of the proposed subduction initiation in the western margin of Philippine Sea plate is yet to be constrained. The late Oligocene to early Miocene onset of true basinal sedimentation in the Central Valley basin provides a minimum docking age between Zambales ophiolite and eastern Luzon (Bachman et al., 1983). The GPlates-based reconstruction presented here, using unfolded slab data (Wu et al., 2016), is essentially similar to the Philippine Sea plate evolutionary models of Deschamps and Lallemand (2003). Although it is beyond the scope of this study to identify the nature of a preexisting structural boundary as a transform fault or strike-slip extension of a subduction zone, we note that both Zambales and IBM are orthogonal to the West Philippine basin spreading center and the Cretaceous arc terranes in the overriding plate. Contrary to a subduction initiation origin, Lallemand (2016) posits that proto-arc basalts (or forearc basalts) formed in short-lived Eocene oceanic basins (e.g., Kita-Daito and Minami-Daito basins) bounded by the Cretaceous arc terranes. We believe that this might be the case for Eocene ophiolites in eastern Philippines (e.g., Angat ophiolite) but not for the Zambales ophiolite. The early Eocene age $(48.1 \pm 0.5 \mathrm{Ma})$ of Angat ophiolite does not necessarily prove an affinity with Zambales as suggested by Encarnación et al. (1993), rather it simply demonstrates that basement complexes in the Philippine Mobile Belt consists of juxtaposed geochemically distinct Eocene and Cretaceous ophiolites (ophiolite belts $1 \mathrm{~B}$ and $1 \mathrm{C}$ of Tamayo et al., 2004) (Fig. 1a). Slightly older Eocene ages (e.g., $50.83 \pm 3.35 \mathrm{Ma})$ were obtained by subsequent whole-rock 


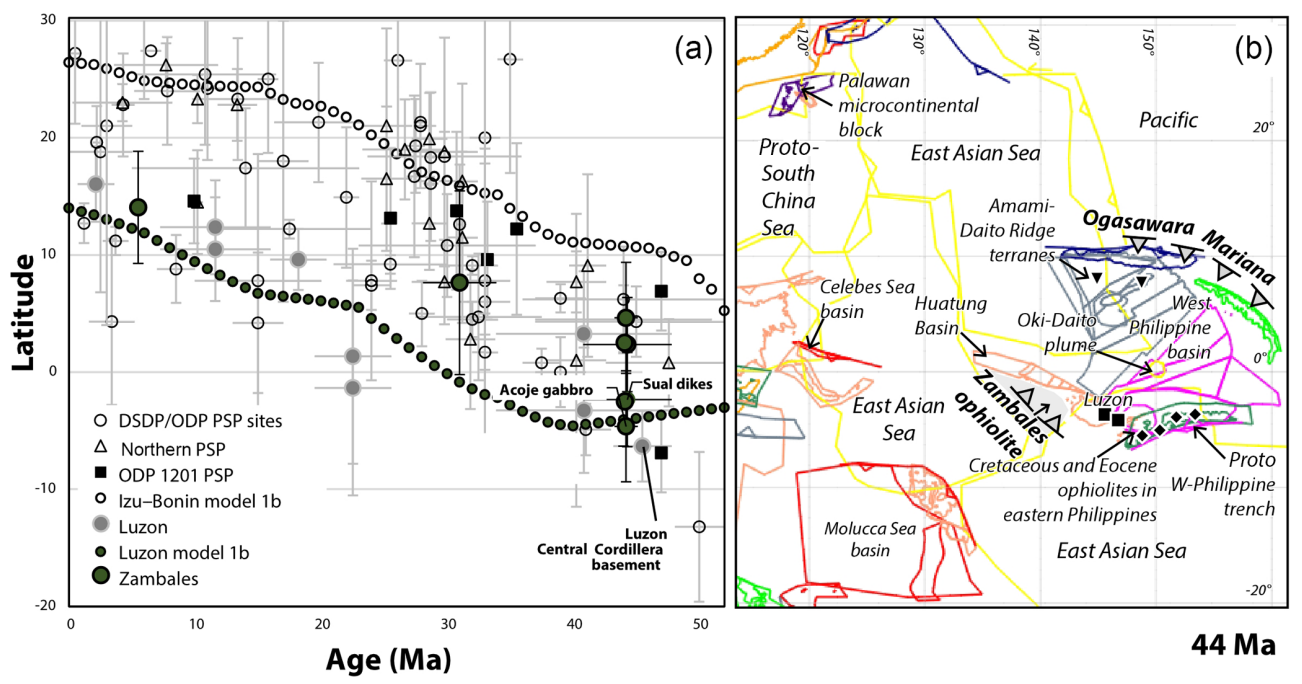

Figure 10. (a) Paleolatitudes derived from Philippine Sea plate, Luzon and Zambales inclination data (Fuller et al., 1991; Hall et al., 1995; Queano et al., 2007, 2009; Richter and Ali, 2015; Yamazaki et al., 2010). (b) Tectonic reconstruction of the western Pacific region at 44 Ma using GPlates (Boyden et al., 2011) and unfolded slab data, plate polygons and the rotation files (model 1b) of Wu et al. (2016). Inverted triangles, diamonds and squares previously shown in Fig. 1b. refer to Cretaceous arc terranes in the northern Philippine Sea plate and Cretaceous-Eocene ophiolites in eastern Philippines, respectively.

$\mathrm{K}-\mathrm{Ar}$ and SHRIMP zircon U-Pb dating of ophiolitic samples from eastern Luzon (Sajona, 1995; Tani et al., 2015). In addition, these Cretaceous and Eocene ophiolites are associated with Eocene volcano-sedimentary arc sequences (Caraballo, Maybangain, Anawan and Payo formations) (Billedo et al., 1996; David et al., 1997). This differs sharply with the deep-marine, isolated environment deduced from the Eocene sedimentary carapace of the Zambales ophiolite (Schweller and Karig, 1982).

Although current terrestrial subduction is dominantly asymmetric, it is interesting to note that two-sided subduction is what is essentially produced in 2-D and 3-D models of mantle convection (Gerya et al., 2008; Wada and King, 2015). Likewise, we discern that doubly vergent subduction initiation (SI) geometry or subduction initiation with oppositely dipping subduction zones along its margins is characteristic of 3-D thermomechanical models of plumeinduced subduction initiation (Baes et al., 2016; Gerya et al., 2015). Plume-induced subduction initiation was first recognized by Whattam and Stern (2015) to describe the temporal association of late Cretaceous plume-related oceanic plateaus in Central America which was followed by arc volcanism with oppositely dipping slab dispositions. In the case of the Eocene western Pacific, a mantle plume centered on the Manus Basin had originally been invoked by Macpherson and Hall (2001) to account for an inferred thermal anomaly in IBM boninite mantle source, implicitly connecting the initiation of the IBM arc to the presence of a mantle plume. Isotopic studies are in agreement that a mantle plume is likely associated with the oceanic plateaus and bathymetric highs emplaced at the same time as the opening of the West
Philippine basin (Hickey-Vargas et al., 2006; Ishizuka et al., 2013); however, thermal anomalies in excess of the ambient mantle are not reflected in mantle potential temperature estimates of proto-arc basalt from the IBM forearc (Umino et al., 2018). A causative link between a mantle plume and the doubly vergent SI configuration along Philippine Sea plate margins is yet to be established. We speculate that the location of Philippine Sea plate (PSP) in the nexus of the Pacific, Indo-Australian and Eurasian plates and their long-term Cenozoic plate motion makes doubly vergent subduction initiation along its margins feasible. The northwestward translation and clockwise rotation of the Philippine Sea plate starting in the early Eocene had to be accommodated by the adjoining oceanic domain east of southern Eurasia (e.g., East Asian Sea); hence, its interaction with the oceanic leading edge of the Philippine Sea plate is expected (Wu et al., 2016; Zahirovic et al., 2016) and likely led to incipient subduction (Fig. 10). The dynamics of sustained double-vergent subduction is examined by Holt et al. (2017) but doubly vergent subduction initiation is yet to be explored by numerical modeling. Field and petrologic data presented here demonstrate that models of subduction initiation based on the IBM forearc are currently simplistic. Geodynamic models of subduction initiation should be founded on robust geologic data and a doubly vergent SI configuration based on the Zambales ophiolite provides another boundary condition for refined models of SI along PSP margins. We advocate that geodynamic models of subduction initiation along Philippine Sea plate margins incorporate a pre-Eocene, N-NE-dipping subduction zone (the proto West Philippine trench of Faccenna et al., 2010) associated with Cretaceous terranes forming the 
overriding plate, doubly vergent subduction initiation along its margins as well as the interplay of plate forces and mantle upwelling (e.g., Oki-Daito plume of Ishizuka et al., 2013) during incipient subduction (Fig. 10b).

\section{Conclusions}

1. The extrusive sequence in the juvenile arc section of the Zambales ophiolite in Luzon Island in the Philippines consists of boninite and boninite-series volcanics. This makes northern Zambales ophiolite the lone middle Eocene boninite locality in the Philippine Sea plate apart from the Ogasawara islands, Guam and their submarine equivalent in the IBM forearc.

2. Zambales boninite and boninite series volcanics are marked by low trace element abundances relative to mid-ocean ridge basalt with hydrous fluid mobile element enrichment and heavy rare earth element depletion, which is comparable with boninite from Troodos and Oman. Trace element ratios suggest that aqueous fluids released from shallow sub-arc depths are the dominant slab components in Zambales boninite.

3. Subduction initiation stratigraphy deduced from diving, dredging and drilling programs in the Izu-Ogasawara (Bonin)-Mariana forearc is recognized in the Zambales ophiolite as well. The temporal variation from proto-arc basalt to boninite and post-boninite arc tholeiite is represented by the Coto (45 Ma), Barlo (44 Ma) and SualSubic (44-43 Ma) volcanic sections of Zambales ophiolite. Incipient subduction associated with the juvenile arc in the northern Zambales ophiolite likely involved the unfolded East Asian Sea crust as the subducting slab and the westernmost margin of Philippine Sea plate as the overriding plate.

4. By studying the Zambales ophiolite, it can be shown that subduction initiation is a plate-scale process. To address Eocene western Pacific subduction initiation, it is essential to consider not just the Izu-OgasawaraMariana forearc but also geologic constraints from the entire Philippine Sea plate. Doubly vergent subduction initiation deduced from the rock record is a testable mechanism that can be explored by geodynamic modeling.

Data availability. The data associated with this publication are available in the Supplement.

The Supplement related to this article is available online at https://doi.org/10.5194/se-9-713-2018-supplement.
Competing interests. The authors declare that they have no conflict of interest.

Acknowledgements. This work forms part of the first author's research project under a Ministry of Education, Culture, Sports, Science and Technology (MEXT) PhD scholarship. The field expedition to the Zambales ophiolite was supported by a 2016 Fukada Geological Institute Grant-in-Aid to Americus Perez. This work was also supported by JSPS KAKENHI grant no. 25400446 and donated funds from JAPEX to Susumu Umino, in addition to grant no. 25287133 to Osamu Ishizuka. We thank Ferdinand Jumawan, Alexer Mapa, Betchaida Payot, Juan Miguel Guotana and Efren Gadot for their assistance during the March 2015 reconnaissance and May 2016 field campaigns. We are grateful to Kiyo Yamanobe and Akihiro Tamura for their help during geochemical analyses at GSJ and Kanazawa. We thank Scott Whattam and John Encarnacion for their constructive reviews.

Edited by: Patrice Rey

Reviewed by: Scott Whattam and John Encarnacion

\section{References}

Abrajano, T. A., Pasteris, J. D., and Bacuta, G. C.: Zambales ophiolite, Philippines I. Geology and petrology of the critical zone of the Acoje massif, Tectonophysics, 168, 65-100, https://doi.org/10.1016/0040-1951(89)90369-7, 1989.

Arculus, R. J., Pearce, J. A., Murton, B. and van der Laan, S. Igneous stratigraphy and major element geochemistry of Holes 786A and 786B, in: Proc. ODP Sci. Results, edited by: Fryer, P., Pearce, J. A., Stokking, L. B., 143-169, Ocean Drilling Program, College Station, TX (Ocean Drilling Program), USA, https://doi.org/10.2973/odp.proc.sr.125.137.1992, 1992.

Arculus, R. J., Ishizuka, O., Bogus, K. A., Gurnis, M., HickeyVargas, R., Aljahdali, M. H., Bandini-Maeder, A. N., Barth, A. P., Brandl, P. A., Drab, L., do Monte Guerra, R., Hamada, M., Jiang, F., Kanayama, K., Kender, S., Kusano, Y., Li, H., Loudin, L. C., Maffione, M., Marsaglia, K. M., McCarthy, A., Meffre, S. Morris, A., Neuhaus, M., Savov, I. P., Sena, C., Tepley III, F. J., van der Land, C., Yogodzinski, G. M., and Zhang, Z.: A record of spontaneous subduction initiation in the Izu-Bonin-Mariana arc, Nat. Geosci., 8, 728-733, https://doi.org/10.1038/ngeo2515, 2015.

Bachman, S. B., Lewis, S. D., and Schweller, W. J.: Evolution of a Forearc Basin, Luzon Central Valley, Philippines, Am. Assoc. Petr. Geol. B., 67, 1143-1162, 1983.

Bacuta, G. C., Kay, R. W., Gibbs, A. K., and Lipin, B. R.: Platinum-group element abundance and distribution in chromite deposits of the Acoje Block, Zambales Ophiolite Complex, Philippines, J. Geochemical Explor., 37, 113-145, https://doi.org/10.1016/0375-6742(90)90086-P, 1990.

Baes, M., Gerya, T., and Sobolev, S. V.: 3-D thermomechanical modeling of plume-induced subduction initiation, Earth Planet. Sc. Lett., 453, 193-203, https://doi.org/10.1016/J.EPSL.2016.08.023, 2016.

Barrat, J. A., Zanda, B., Moynier, F., Bollinger, C., Liorzou, C., and Bayon, G.: Geochemistry of CI chondrites: Major and trace 
elements, and $\mathrm{Cu}$ and $\mathrm{Zn}$ Isotopes, Geochim. Cosmochim. Ac., 83, 79-92, https://doi.org/10.1016/j.gca.2011.12.011, 2012.

Bedard, J. H.: Petrogenesis of Boninites from the Betts Cove Ophiolite, Newfoundland, Canada: Identification of Subducted Source Components, J. Petrol., 40, 1853-1889, https://doi.org/10.1093/petroj/40.12.1853, 1999.

Billedo, E., Stephan, J. F., Delteil, J., Bellon, H., Sajona, F. G., and Feraud, G.: The pre-Tertiary ophiolitic complex of Northeastern Luzon and the Polilio Group of Islands, Philippines, J. Geol. Soc. Philipp., 51, 95-114, 1996.

Blenkinsop, T. G.: Visualizing structural geology: From Excel to Google Earth, Comput. Geosci., 45, 52-56, https://doi.org/10.1016/j.cageo.2012.03.007, 2012.

Bloomer, S. H. and Hawkins, J. W.: Petrology and geochemistry of boninite series volcanic rocks from the Mariana trench, Contrib. Mineral. Petrol., 97, 361-377, https://doi.org/10.1007/BF00371999, 1987.

Boyden, J. A., Müller, R. D., Gurnis, M., Torsvik, T. H., Clark, J. A., Turner, M., Ivey-Law, H., Watson, R. J., and Cannon, J. S.: Next-generation plate-tectonic reconstructions using GPlates, in: Geoinformatics: Cyberinfrastructure for the Solid Earth Sciences, edited by: Baru, C. and Keller, G. R., Cambridge University Press, Cambridge, UK, 95-114, 2011.

Brounce, M., Kelley, K. A., Cottrell, E., and Reagan, M. K.: Temporal evolution of mantle wedge oxygen fugacity during subduction initiation, Geology, 43, 775-778, https://doi.org/10.1130/G36742.1, 2015.

Cameron, W. E.: Petrology and origin of primitive lavas from the Troodos ophiolite, Cyprus, Contrib. Mineral. Petrol., 89, 239255, https://doi.org/10.1007/BF00379457, 1985.

Cameron, W. E.: Contrasting boninite-tholeite associations from New Caledonia, in: Boninites and Related Rocks, edited by: Crawford, A. J., Unwin-Hyman, London, UK, 314-338, 1989.

Carter, L. B., Skora, S., Blundy, J. D., De Hoog, J. C. M., and Elliott, T.: An experimental study of trace element fluxes from subducted oceanic crust, J. Petrol., 56, 1585-1606, https://doi.org/10.1093/petrology/egv046, 2015.

Cluzel, D., Ulrich, M., Jourdan, F., Meffre, S., Paquette, J.-L., Audet, M.-A., Secchiari, A., and Maurizot, P.: Early Eocene clinoenstatite boninite and boninite-series dikes of the ophiolite of New Caledonia; a witness of slab-derived enrichment of the mantle wedge in a nascent volcanic arc, Lithos, 260, 429-442, https://doi.org/10.1016/j.lithos.2016.04.031, 2016.

Crameri, F. and Tackley, P. J.: Subduction initiation from a stagnant lid and global overturn: new insights from numerical models with a free surface, Prog. Earth Planet. Sci., 3, 1-19, https://doi.org/10.1186/s40645-016-0103-8, 2016.

Crawford, A. J., Falloon, T. J., and Green, D. H.: Classification, petrogenesis and tectonic setting of boninites, in: Boninites and Related Rocks, edited by: Crawford, A. J., Unwin-Hyman, London, UK, 1-49, 1989.

David, S., Stephan, J.-F., Delteil, J., Müller, C., Butterlin, J., Bellon, H., and Billedo, E.: Geology and tectonic history of Southeastern Luzon, Philippines, J. Asian Earth Sci., 15, 435-452, https://doi.org/10.1016/S0743-9547(97)00027-5, 1997.

Deschamps, A. and Lallemand, S.: The West Philippine Basin: An Eocene to early Oligocene back arc basin opened between two opposed subduction zones, J. Geophys. Res.-Sol. Ea., 107, EPM 1-1-EPM 1-24, https://doi.org/10.1029/2001JB001706, 2002.
Deschamps, A. and Lallemand, S.: Geodynamic setting of IzuBonin-Mariana boninites, Geol. Soc. London, Spec. Publ., 219, 163-185, https://doi.org/10.1144/GSL.SP.2003.219.01.08, 2003.

Dietrich, V., Emmermann, R., Oberhänsli, R., and Puchelt, H.: Geochemistry of basaltic and gabbroic rocks from the West Mariana basin and the Mariana trench, Earth Planet. Sc. Lett., 39, 127144, https://doi.org/10.1016/0012-821X(78)90149-8, 1978.

Dobson, P. F., Blank, J. G., Maruyama, S., and Liou, J. G.: Petrology and geochemistry of boninite-series volcanic rocks, Chichi-Jima, Bonin Islands, Japan, Int. Geol. Rev., 48, 669-701, https://doi.org/10.2747/0020-6814.48.8.669, 2006.

Dulski, P.: Reference materials for geochemical studies: New analytical data by ICP-MS and critical discussion of reference values, Geostand. Newsl., 25, 87-125, https://doi.org/10.1111/j.1751-908X.2001.tb00790.x, 2001.

Elliott, T.: Tracers of the slab, in: Inside the Subduction Factory, vol. 138, edited by: Eiler, J., American Geophysical Union, Washington, D.C., USA, 23-45, 2003.

Encarnación, J.: Multiple ophiolite generation preserved in the northern Philippines and the growth of an island arc complex, Tectonophysics, 392, 103-130, https://doi.org/10.1016/J.TECTO.2004.04.010, 2004.

Encarnación, J., Mukasa, S. B., and Evans, C. A.: Subduction components and the generation of arc-like melts in the Zambales ophiolite, Philippines: $\mathrm{Pb}, \mathrm{Sr}$ and $\mathrm{Nd}$ isotopic constraints, Chem. Geol., 156, 343-357, https://doi.org/10.1016/S00092541(98)00190-9, 1999.

Encarnación, J. P., Mukasa, S. B., and Obille, E. C.: Zircon U-Pb geochronology of the Zambales and Angat Ophiolites, Luzon, Philippines: Evidence for an Eocene arcback arc pair, J. Geophys. Res.-Sol. Ea., 98, 19991-20004, https://doi.org/10.1029/93JB02167, 1993.

Evans, C. and Hawkins, J. W.: Compositional heterogeneities in upper mantle peridotites from the Zambales Range Ophiolite, Luzon, Philippines, Tectonophysics, 168, 23-41, https://doi.org/10.1016/0040-1951(89)90367-3, 1989.

Evans, C. A., Casteneda, G., and Franco, H.: Geochemical complexities preserved in the volcanic rocks of the Zambales Ophiolite, Philippines, J. Geophys. Res.-Sol. Ea., 96, 16251-16262, https://doi.org/10.1029/91JB01488, 1991.

Faccenna, C., Becker, T. W., Lallemand, S., Lagabrielle, Y., Funiciello, F., and Piromallo, C.: Subduction-triggered magmatic pulses: A new class of plumes?, Earth Planet. Sc. Lett., 299, 54 68, https://doi.org/10.1016/J.EPSL.2010.08.012, 2010.

Falloon, T. J. and Crawford, A. J.: The petrogenesis of high-calcium boninite lavas dredged from the northern Tonga ridge, Earth Planet. Sc. Lett., 102, 375-394, https://doi.org/10.1016/0012821X(91)90030-L, 1991.

Falloon, T. J. and Danyushevsky, L. V: Melting of refractory mantle at $1.5,2$ and $2.5 \mathrm{GPa}$ under anhydrous and $\mathrm{H}_{2} \mathrm{O}$-undersaturated conditions: Implications for the petrogenesis of high-Ca boninites and the influence of subduction components on mantle melting, J. Petrol., 41, 257-283, https://doi.org/10.1093/petrology/41.2.257, 2000.

Falloon, T. J., Danyushevsky, L. V., Crawford, T. J., Maas, R., Woodhead, J. D., Eggins, S. M., Bloomer, S. H., Wright, D. J., Zlobin, S. K., and Stacey, A. R.: Multiple mantle plume components involved in the petrogenesis of subduction-related lavas from the northern termination of the Tonga Arc and northern 
Lau Basin: Evidence from the geochemistry of arc and backarc submarine volcanics, Geochem., Geophy. Geosy., 8, Q09003, https://doi.org/10.1029/2007GC001619, 2007.

Florendo, F. F. and Hawkins, J. W.: Comparison of the geochemistry of volcanic rocks of the Zambales Ophiolite, northern Luzon, Philippines: Implications for tectonic setting, Acta Geol. Taiwanica Sci. Reports Natl. Taiwan Univ., 30, 172-176, 1992.

Fuller, M., Haston, R., and Almasco, J.: Paleomagnetism of the Zambales ophiolite, Luzon, northern Philippines, Tectonophysics, 168, 171-203, https://doi.org/10.1016/00401951(89)90375-2, 1989.

Fuller, M., Haston, R., Lin, J. L., Richter, B., Schmidtke, E., and Almasco, J.: Tertiary paleomagnetism of regions around the South China Sea, J. Southe. Asian Earth, 6, 161-184, https://doi.org/10.1016/0743-9547(91)90065-6, 1991.

Gale, A., Dalton, C. A., Langmuir, C. H., Su, Y., and Schilling, J. G.: The mean composition of ocean ridge basalts, Geochem. Geophy. Geosy., 14, 489-518, https://doi.org/10.1029/2012GC004334, 2013.

Geary, E. E., Kay, R. W., Reynolds, J. C., and Kay, S. M.: Geochemistry of mafic rocks from the Coto Block, Zambales ophiolite, Philippines: trace element evidence for two stages of crustal growth, Tectonophysics, 168, 43-63, https://doi.org/10.1016/0040-1951(89)90368-5, 1989.

Gerya, T. V., Connolly, J. A. D., and Yuen, D. A.: Why is terrestrial subduction one-sided?, Geology, 36, 43-46, https://doi.org/10.1130/G24060A.1, 2008.

Gerya, T. V., Stern, R. J., Baes, M., Sobolev, S. V., and Whattam, S. A.: Plate tectonics on the Earth triggered by plume-induced subduction initiation, Nature, 527, 221-225, https://doi.org/10.1038/nature15752, 2015.

Ghiorso, M. S. and Gualda, G. A. R.: An $\mathrm{H}_{2} \mathrm{O}-\mathrm{CO}_{2}$ mixed fluid saturation model compatible with rhyolite-MELTS, Contrib. Mineral. Petrol., 169, 1-30, https://doi.org/10.1007/s00410015-1141-8, 2015.

Grove, T. L., Till, C. B., and Krawczynski, M. J.: The Role of $\mathrm{H}_{2} \mathrm{O}$ in Subduction Zone Magmatism, Annu. Rev. Earth Pl. Sc., 40, 413-439, https://doi.org/10.1146/annurev-earth-042711105310, 2012.

Hall, C. E., Gurnis, M., Sdrolias, M., Lavier, L. L., and Müller, R. D.: Catastrophic initiation of subduction following forced convergence across fracture zones, Earth Planet. Sc. Lett., 212, 1530, https://doi.org/10.1016/S0012-821X(03)00242-5, 2003.

Hall, R., Ali, J. R., Anderson, C. D., and Baker, S. J.: Origin and motion history of the Philippine Sea Plate, Tectonophysics, 251, 229-250, https://doi.org/10.1016/0040-1951(95)00038-0, 1995.

Haugen, E.: Magmatic Evolution of Early Subduction Zones: Geochemical Modeling and Chemical Stratigraphy of Boninite and Fore Arc Basalt from the Bonin Fore Arc, MSc Thesis, Utah State University., available at: http://digitalcommons.usu.edu/ etd/5934, last access: 7 June 2017.

Hawkins, J. W. and Evans, C. A.: Geology of the Zambales Range, Luzon, Philippine Islands: Ophiolite Derived from an Island ArcBack Arc Basin Pair, in: The Tectonic and Geologic Evolution of Southeast Asian Seas and Islands: Part 2, Geophyical Monograph Series vol. 27, edited by: Hayes, D. E., American Geophysical Union, Washington, D.C., USA, 95-123, 1983.

Head, J. W. and Wilson, L.: Deep submarine pyroclastic eruptions: theory and predicted landforms and deposits, J. Volcanol.
Geotherm. Res., 121, 155-193, https://doi.org/10.1016/S03770273(02)00425-0, 2003.

Hickey-Vargas, R., Savov, I. P., Bizimis, M., Ishii, T., and Fujioka, K.: Origin of Diverse Geochemical Signatures in Igneous Rocks from the West Philippine Basin: Implications for Tectonic Models, American Geophysical Union, Washington, D.C., USA, 287-303, 2006.

Hickey-Vargas, R., Yogodzinski, G. M., Ishizuka, O., McCarthy, A., Bizimis, M., Kusano, Y., Savov, I. P., and Arculus, R.: Origin of depleted basalts during subduction initiation and early development of the Izu-Bonin-Mariana island arc: Evidence from IODP expedition 351 site U1438, Amami-Sankaku basin, Geochim. Cosmochim. Ac., 229, 85111, https://doi.org/10.1016/J.GCA.2018.03.007, 2018.

Holt, A. F., Royden, L. H., and Becker, T. W.: The dynamics of double slab subduction, Geophys. J. Int., 209, 250-265, https://doi.org/10.1093/gji/ggw496, 2017.

Ishikawa, T., Nagaishi, K., and Umino, S.: Boninitic volcanism in the Oman ophiolite: Implications for thermal condition during transition from spreading ridge to arc, Geology, 30, 899-902, https://doi.org/10.1130/00917613(2002)030<0899:BVITOO>2.0.CO;2, 2002.

Ishizuka, O., Tani, K., Reagan, M. K., Kanayama, K., Umino, S., Harigane, Y., Sakamoto, I., Miyajima, Y., Yuasa, M., and Dunkley, D. J.: The timescales of subduction initiation and subsequent evolution of an oceanic island arc, Earth Planet. Sc. Lett., 306, 229-240, https://doi.org/10.1016/j.epsl.2011.04.006, 2011.

Ishizuka, O., Taylor, R. N., Ohara, Y., and Yuasa, M.: Upwelling, rifting, and age-progressive magmatism from the Oki-Daito mantle plume, Geology, 41, 1011-1014, https://doi.org/10.1130/G34525.1, 2013.

Ishizuka, O., Umino, S., Taylor, R. N., and Kanayama, K.: Evidence for hydrothermal activity in the earliest stages of intraoceanic arc formation: Implications for ophiolitehosted hydrothermal activity, Econ. Geol., 109, 2159-2177, https://doi.org/10.2113/econgeo.109.8.2159, 2014.

Ishizuka, O., Hickey-Vargas, R., Arculus, R. J., Yogodzinski, G. M., Savov, I. P., Kusano, Y., Mccarthy, A., Brandl, P. A., and Sudo, M.: Age of Izu - Bonin - Mariana arc basement, Earth Planet. Sc. Lett., 481, 80-90, https://doi.org/10.1016/j.epsl.2017.10.023, 2018.

Jenner, F. E. and O'Neill, H. S. C.: Analysis of 60 elements in 616 ocean floor basaltic glasses, Geochem. Geophy. Geosy., 13, Q02005, https://doi.org/10.1029/2011GC004009, 2012.

Jenner, G. A.: Geochemistry of high-Mg andesites from Cape Vogel, Papua New Guinea, Chem. Geol., 33, 307-332, https://doi.org/10.1016/0009-2541(81)90106-6, 1981.

Jochum, K. P., Weis, U., Schwager, B., Stoll, B., Wilson, S. A., Haug, G. H., Andreae, M. O., and Enzweiler, J.: Reference Values Following ISO Guidelines for Frequently Requested Rock Reference Materials, Geostand. Geoanal. Res., 40, 333-350, https://doi.org/10.1111/j.1751-908X.2015.00392.x, 2016.

Kanayama, K., Umino, S., and Ishizuka, O.: Eocene volcanism during the incipient stage of Izu-Ogasawara Arc: Geology and petrology of the Mukojima Island Group, the Ogasawara Islands, Isl. Arc, 21, 288-316, https://doi.org/10.1111/iar.12000, 2012.

Kanayama, K., Kitamura, K., and Umino, S.: New geochemical classification of global boninites, in: IAVCEI 2013 Scientific Assembly, 20-24 July 2013, Kagoshima, Japan, p. 99, 2013. 
Karig, D. E.: Accreted terranes in the northern part of the Philippine archipelago, Tectonics, 2, 211-236, https://doi.org/10.1029/TC002i002p00211, 1983.

Karig, D. E., Lagoe, M. B., Snow, J. K., Schweller, W. J., and Bacuta, G. C.: Stratigraphy along the Cabaluan River and geologic relations on the west flank of the Zambales Range, Luzon, Philippines, Philipp. Geol., 30, 1-20, 1986.

Keenan, T. E. and Encarnación, J.: Unclear causes for subduction, Nat. Geosci., 9(, 338-338, https://doi.org/10.1038/ngeo2703, 2016.

Keppler, H.: Fluids and trace element transport in subduction zones, Am. Mineral., 102, 5-20, https://doi.org/10.2138/am-2017-5716, 2017.

König, S., Münker, C., Schuth, S., and Garbe-Schönberg, D.: Mobility of tungsten in subduction zones, Earth Planet. Sc. Lett., 274, 82-92, https://doi.org/10.1016/j.epsl.2008.07.002, 2008.

König, S., Münker, C., Schuth, S., Luguet, A., Hoffmann, J. E., and Kuduon, J.: Boninites as windows into trace element mobility in subduction zones, Geochim. Cosmochim. Ac., 74, 684-704, https://doi.org/10.1016/j.gca.2009.10.011, 2010.

Kostopoulos, D. K. and Murton, B. J.: Origin and distribution of components in boninite genesis: significance of the OIB component, Geol. Soc. London, Spec. Publ., 60, 133-154, https://doi.org/10.1144/GSL.SP.1992.060.01.08, 1992.

Kuroda, N., Shiraki, K., and Urano, H.: Boninite as a possible calc-alkalic primary magma, B. Volcanol., 41, 563-575, https://doi.org/10.1007/BF02597387, 1978.

Kusano, Y., Hayashi, M., Adachi, Y., Umino, S., and Miyashita, S.: Evolution of volcanism and magmatism during initial arc stage: constraints on the tectonic setting of the Oman Ophiolite, Geol. Soc. London, Spec. Publ., 392, 177-193, https://doi.org/10.1144/SP392.9, 2014.

Kusano, Y., Umino, S., Shinjo, R., Ikei, A., Adachi, Y., Miyashita, S., and Arai, S.: Contribution of slab-derived fluid and sedimentary melt in the incipient arc magmas with development of the paleo-arc in the Oman Ophiolite, Chem. Geol., 449, 206-225, https://doi.org/10.1016/j.chemgeo.2016.12.012, 2017.

Lallemand, S.: Philippine Sea Plate inception, evolution, and consumption with special emphasis on the early stages of IzuBonin-Mariana subduction, Prog. Earth Planet. Sci., 3, 1-26, https://doi.org/10.1186/s40645-016-0085-6, 2016.

Le Maitre, R. W.: Igneous Rocks. A Classification and Glossary of Terms. Recommendations of the International Union of Geological Sciences Subcommission on the Systematics of Igneous Rocks, edited by: Le Maitre, R. W., Cambridge University Press, Cambridge, UK, New York, USA, Melbourne, Australia, 2002.

Leng, W. and Gurnis, M.: Subduction initiation at relic arcs, Geophys. Res. Lett., 42, 7014-7021, https://doi.org/10.1002/2015GL064985, 2015.

Leng, W., Gurnis, M., and Asimow, P.: From basalts to boninites: The geodynamics of volcanic expression during induced subduction initiation, Lithosphere, 4, 511-523, https://doi.org/10.1130/L215.1, 2012.

Li, Y. B., Kimura, J. I., Machida, S., Ishii, T., Ishiwatari, A., Maruyama, S., Qiu, H. N., Ishikawa, T., Kato, Y., Haraguchi, S., Takahata, N., Hirahara, Y., and Miyazaki, T.: High-Mg adakite and low-Ca boninite from a bonin fore-arc seamount: Implications for the reaction between slab melts and depleted mantle, J. Petrol., 54, 1149-1175, https://doi.org/10.1093/petrology/egt008, 2013.

Macpherson, C. G. and Hall, R.: Tectonic setting of Eocene boninite magmatism in the Izu-Bonin-Mariana forearc, Earth Planet. Sc. Lett., 186, 215-230, https://doi.org/10.1016/S0012821X(01)00248-5, 2001.

Mallmann, G. and O'Neill, H. S. C.: The Crystal/Melt Partitioning of $\mathrm{V}$ during Mantle Melting as a Function of Oxygen Fugacity Compared with some other Elements (Al, P, Ca, Sc, Ti, Cr, Fe, Ga, Y, Zr and Nb), J. Petrol., 50, 1765-1794, https://doi.org/10.1093/petrology/egp053, 2009.

Meijer, A.: Primitive arc volcanism and a boninite series; example from western Pacific Island arcs, in: The Tectonic and Geologic Evolution of Southeast Asian Seas and Islands, American Geophysical Union, Washington, D.C., USA, 269-282, 1980.

Meijer, A.: Petrology of volcanic rocks from the fore-arc sites, edited by: Anthony, E., Reagan, M., Lee, M., Powell, R., Hussong, D. M., Uyeda, S., Blanchet, R., Bleil, U., Ellis, C. H., Francis, T., Fryer, P., Horai, K.-I., Kling, S., Meijer, A., Nakamura, K., Natland, J. H., Packham, G. H., and Sharaskin, A. Y., Initial Reports Deep Sea Drill. Proj., 60, 709-729, https://doi.org/10.2973/dsdp.proc.60.138.1982, 1982.

Miyashiro, A.: Volcanic rock series in island arcs and active continental margins, Am. J. Sci., 274, 321-355, https://doi.org/10.2475/ajs.274.4.321, 1974.

Münker, C., Pfänder, J. A., Weyer, S., Büchl, A., Kleine, T., and Mezger, K.: Evolution of planetary cores and the EarthMoon system from Nb/Ta systematics, Science, 301, 84-87, https://doi.org/10.1126/science.1084662, 2003.

Nagaishi, K.: Fluid transfer and magmatism in the initial stage of subduction: Inference from the Oman ophiolite, PhD Thesis, Shizuoka University, Shizuoka, Japan, available at: http://ir. lib.shizuoka.ac.jp/handle/10297/6386 (last access: 30 November 2017), 2008.

Natland, J. H.: Crystal Morphologies and Pyroxene Compositions in Boninites and Tholeiitic Basalts from Deep Sea Drilling Project Holes 458 and 459B in the Mariana Fore-Arc Region, Initial Reports Deep Sea Drill. Proj., 60, 681-707, https://doi.org/10.2973/dsdp.proc.60.137.1982, 1982.

Osozawa, S., Shinjo, R., Lo, C.-H., Jahn, B.-M., Hoang, N., Sasaki, M., Ishikawa, K., Kano, H., Hoshi, H., Xenophontos, C., and Wakabayashi, J.: Geochemistry and geochronology of the Troodos ophiolite: An SSZ ophiolite generated by subduction initiation and an extended episode of ridge subduction?, Lithosphere, 4, 497-510, https://doi.org/10.1130/L205.1, 2012.

Paringit, R.: Notes on the massive copper-pyrite deposits and exploration concepts applied at Barlo, Dasol, Pangasinan, J. Geol. Soc. Philipp., 31, 1-6, 1977.

Pearce, J. A. and Parkinson, I. J.: Trace element models for mantle melting: application to volcanic arc petrogenesis, Geol. Soc. London, Spec. Publ., 76, 373-403, https://doi.org/10.1144/GSL.SP.1993.076.01.19, 1993.

Pearce, J. A. and Robinson, P. T.: The Troodos ophiolitic complex probably formed in a subduction initiation, slab edge setting, Gondwana Res., 18, 60-81, https://doi.org/10.1016/j.gr.2009.12.003, 2010.

Pearce, J. A., van der Laan, S. R., Arculus, R. J., Murton, B. J., Ishii, T., Peate, D. W., and Parkinson, I. J.: Boninite and harzburgite from Leg 125 (Bonin-Mariana forearc); a case 
study of magma genesis during the initial stages of subduction, Proc. Ocean Drill. Program, Sci. Results, 125, 623-659, https://doi.org/10.2973/odp.proc.sr.125.172.1992, 1992.

Pearce, J. A., Stern, R. J., Bloomer, S. H., and Fryer, P.: Geochemical mapping of the Mariana arc-basin system: Implications for the nature and distribution of subduction components, Geochem. Geophy. Geosy., 6, Q07006, https://doi.org/10.1029/2004GC000895, 2005.

Plank, T.: Constraints from Thorium/Lanthanum on sediment recycling at subduction zones and the evolution of the continent, $\mathrm{J}$. Petrol., 46, 921-944, https://doi.org/10.1093/petrology/egi005, 2005.

Plank, T.: 4.17 - The chemical composition of subducting sediments, in: Treatise on Geochemistry, Elsevier, Italy, 607-629, 2014

Queano, K. L., Ali, J. R., Milsom, J., Aitchison, J. C., and Pubellier, M.: North Luzon and the Philippine Sea Plate motion model: Insights following paleomagnetic, structural, and age-dating investigations, J. Geophys. Res., 112, B05101, https://doi.org/10.1029/2006JB004506, 2007.

Queaño, K. L., Ali, J. R., Pubellier, M., Yumul, G. P., and Dimalanta, C. B.: Reconstructing the Mesozoic-early Cenozoic evolution of northern Philippines: clues from palaeomagnetic studies on the ophiolitic basement of the Central Cordillera, Geophys. J. Int., 178, 1317-1326, https://doi.org/10.1111/j.1365246X.2009.04221.x, 2009.

Queaño, K. L., Marquez, E. J., Dimalanta, C. B., Aitchison, J. C., Ali, J. R., and Yumul, G. P.: Mesozoic radiolarian faunas from the northwest Ilocos Region, Luzon, Philippines and their tectonic significance, Isl. Arc, 26, e12195, https://doi.org/10.1111/iar.12195, 2017a.

Queaño, K. L., Dimalanta, C. B., Yumul, G. P., Marquez, E. J., Faustino-Eslava, D. V, Suzuki, S., and Ishida, K.: Stratigraphic units overlying the Zambales Ophiolite Complex (ZOC) in Luzon, (Philippines): Tectonostratigraphic significance and regional implications, J. Asian Earth Sci., 142, 20-31, https://doi.org/10.1016/j.jseaes.2016.06.011, 2017 b.

Reagan, M. K. and Meijer, A. I.: Geology and geochemistry of early arc-volcanic rocks from Guam., Geol. Soc. Am. Bull., 95, 701-713, https://doi.org/10.1130/00167606(1984)95<701:GAGOEA>2.0.CO;2, 1984.

Reagan, M. K., Ishizuka, O., Stern, R. J., Kelley, K. A., Ohara, Y., Blichert-Toft, J., Bloomer, S. H., Cash, J., Fryer, P., Hanan, B. B., Hickey-Vargas, R., Ishii, T., Kimura, J.-I., Peate, D. W., Rowe, M. C., and Woods, M.: Fore-arc basalts and subduction initiation in the Izu-Bonin-Mariana system, Geochem. Geophy. Geosy., 11, Q03X12, https://doi.org/10.1029/2009GC002871, 2010.

Reagan, M. K., Pearce, J. A., Petronotis, K., Almeev, R., Avery, A. J., Carvallo, C., Chapman, T., Christeson, G. L., Ferré, E. C., Godard, M., Heaton, D. E., Kirchenbaur, M., Kurz, W., Kutterolf, S., Hongyan, L., Yibing, L., Michibayashi, K., Morgan, S., Nelson, W. R., Prytulak, J., Python, M., Robertson, A. H. F., Ryan, J. G., Sager, W. W., Sakuyama, T., Shervais, J. W., Shimizu, K., and Whattam, S. A.: Expedition 352 summary, Proc. Int. Ocean Discov. Progr., 352, 1-32, https://doi.org/10.14379/iodp.proc.352.102.2015, 2015.

Reagan, M. K., Pearce, J. A., Petronotis, K., Almeev, R. R., Avery, A. J., Carvallo, C., Chapman, T., Christeson, G. L., Ferré, E. C., Godard, M., Heaton, D. E., Kirchenbaur, M., Kurz, W.,
Kutterolf, S., Li, H., Li, Y., Michibayashi, K., Morgan, S., Nelson, W. R., Prytulak, J., Python, M., Robertson, A. H. F., Ryan, J. G., Sager, W. W., Sakuyama, T., Shervais, J. W., Shimizu, K., and Whattam, S. A.: Subduction initiation and ophiolite crust: new insights from IODP drilling, Int. Geol. Rev., 59, 1439-1450, https://doi.org/10.1080/00206814.2016.1276482, 2017.

Ribeiro, J. M., Stern, R. J., Kelley, K. A., Shaw, A. M., Martinez, F., and Ohara, Y.: Composition of the slab-derived fluids released beneath the Mariana forearc: Evidence for shallow dehydration of the subducting plate, Earth Planet. Sc. Lett., 418, 136-148, https://doi.org/10.1016/j.epsl.2015.02.018, 2015.

Richter, C. and Ali, J. R.: Philippine Sea Plate motion history: Eocene-Recent record from ODP Site 1201, central West Philippine Basin, Earth Planet. Sc. Lett., 410, 165-173, https://doi.org/10.1016/j.eps1.2014.11.032, 2015.

Sajona, F. G.: Fusion de la croute oceanique en contexte de subduction/collision: Geochimie, geochronologie et petrologie du magmatisme Plioquaternaire de Mindanao (Philippines), $\mathrm{PhD}$ Thesis, Universite de Bretagne Occidentale, Brest, France, 1995.

Salapare, R. C., Dimalanta, C. B., Ramos, N. T., Manalo, P. C., Faustino-Eslava, D. V., Queano, K. L., and Yumul, G. P.: Upper crustal structure beneath the Zambales Ophiolite Complex, Luzon, Philippines inferred from integrated gravity, magnetic and geological data, Geophys. J. Int., 201, 1522-1533, https://doi.org/10.1093/gji/ggv094, 2015.

Savov, I. P., Hickey-Vargas, R., D’Antonio, M., Ryan, J, G., and Spadea, P.: Petrology and Geochemistry of West Philippine Basin Basalts and Early Palau-Kyushu Arc Volcanic Clasts from ODP Leg 195, Site 1201D: Implications for the Early History of the Izu-Bonin-Mariana Arc, J. Petrol., 47, 277-299, https://doi.org/10.1093/petrology/egi075, 2006.

Schweller, W. J. and Karig, D. E.: Emplacement of the Zambales Ophiolite into the West Luzon Margin, in: AAPG Memoir 34: Studies in Continental Margin Geology, edited by: Watkins, J. S. and Drake, C. L., American Association of Petroleum Geologists, Tulsa, Oklahoma, USA, 441-454, 1982.

Schweller, W. J., Roth, P. H., Karig, D. E., and Bachman, S. B.: Sedimentation history and biostratigraphy of ophiolite-related Tertiary sediments, Luzon, Philippines, Geol. Soc. Am. Bull., 95, 1333-1342, https://doi.org/10.1130/00167606(1984)95<1333:SHABOO>2.0.CO;2, 1984.

Serri, G., Spadea, P., Beccaluva, L., Civetta, L., Coltorti, M., Dostal, J., Sajona, F. G., Vaccaro, C., and Zeda, O.: Petrology of igneous rocks from the Celebes Sea basement, edited by: Spadea, P., Beccaluva, L., Civetta, L., Coltorti, M., Dostal, J., Sajona, F. G., Vaccaro, C., Zeda, O., Silver, E. A., Rangin, C., von Breymann, M. T., Berner, U., Bertrand, P., Betzler, C., Brass, G. W., Hsü, V., Huang, Z., Jarrard, R. D., Lewis, S. D., Linsley, B. K., Merrill, D. L., Müller, C. M., Nederbragt, A. J., Nichols, G. J., Pubellier, M., Sajona, F. G., Scherer, R. P., Sheu, D. D., Shibuya, H., Shyu, J.-P., Smith, R. B., Smith, T., Solidum, R. U., Spadea, P., Tannant, D. D., and Winkler, W. R., Proc. Ocean Drill. Program, Sci. Results, 124, 271-296, https://doi.org/10.2973/odp.proc.sr.124.160.1991, 1991.

Sharaskin, A. Y.: Petrography and geochemistry of basement rocks from five Leg 60 sites, Initial Reports Deep Sea Drill. Proj., 60, 647-656, https://doi.org/10.2973/dsdp.proc.60.134.1982, 1982. 
Shervais, J. W.: TiV plots and the petrogenesis of modern and ophiolitic lavas, Earth Planet. Sc. Lett., 59, 101-118, https://doi.org/10.1016/0012-821X(82)90120-0, 1982.

Spadea, P., D'Antonio, M., and Thirlwall, M. F.: Source characteristics of the basement rocks from the Sulu and Celebes Basins (Western Pacific): chemical and isotopic evidence, Contrib. Mineral. Petrol., 123, 159-176, https://doi.org/10.1007/s004100050148, 1996.

Stern, R. J.: Subduction initiation: spontaneous and induced, Earth Planet. Sc. Lett., 226, 275-292, https://doi.org/10.1016/j.eps1.2004.08.007, 2004.

Stern, R. J., Reagan, M., Ishizuka, O., Ohara, Y., and Whattam, S.: To understand subduction initiation, study forearc crust: To understand forearc crust, study ophiolites, Lithosphere, 4, 469-483, https://doi.org/10.1130/L183.1, 2012.

Takahashi, E.: Origin of basaltic magmas-implications from peridotite melting experiments and an olivine fractionation model, B. Volcanol. Soc. Japan, 30, S17-S40, 1986.

Tamayo, R. A., Maury, R. C., Yumul, G. P., Polvé, M., Cotten, J., Dimantala, C. B., and Olaguera, F. O.: Subduction-related magmatic imprint of most Philippine ophiolites: Implications on the early geodynamic evolution of the Philippine archipelago, Bull. Soc. Geol. Fr., 175, 443-460, https://doi.org/10.2113/175.5.443, 2004.

Tamayo Jr., R. A.: Caracterisation petrologique et geochemique, origines et evolutions geodynamiques des ophiolites des Philippines, PhD Thesis, Universite de Bretagne Occidentale, Brest, France, 2001.

Tani, K., Gabo, J. A. S., Horie, K., Ishizuka, O., Padrones, J., Payot, B., Tejada, M. L., Faustino-Eslava, D. V., Imai, A., Arai, S., Hokada, T., Yumul, Jr., G. P., and Dimalanta, C. B.: Temporal constraints for the tectonic development of the Philippine ophiolite belts from new zircon U-Pb ages, in: Japan Geoscience Union Meeting, Chiba, Japan, 2015.

Taylor, R. N., Nesbitt, R. W., Vidal, P., Harmon, R. S., Auvray, B., and Croudace, I. W.: Mineralogy, chemistry, and genesis of the boninite series volcanics, Chichijima, Bonin Islands, Japan, J. Petrol., 35, 577-617, https://doi.org/10.1093/petrology/35.3.577, 1994.

Umino, S.: Magma mixing in boninite sequence of Chichijima, Bonin Islands, J. Volcanol. Geoth. Res., 29, 125-157, https://doi.org/10.1016/0377-0273(86)90042-9, 1986.

Umino, S. and Nakano, S.: Geology of the Chichijima Retto District, Quadrangle Series, 1:50 000, Geological Survey of Japan, AIST, Tsukuba, Japan, 71 pp., 2007 (in Japanese with English abstract).

Umino, S., Lipman, P. W., and Obata, S.: Subaqueous lava flow lobes, observed on ROV dives off Hawaii, Geology, 28, 503-506, https://doi.org/10.1130/00917613(2000)28<503:SLFLOO>2.0.CO;2, 2000.

Umino, S., Obata, S., Lipman, P., Smith, J. R., Shibata, T., Naka, J., and Trusdell, F.: Emplacement and inflation structures of submarine and subaerial from Hawaii, American Geophysical Union, Washington, D.C., USA, 85-101, 2002.

Umino, S., Nakano, S., Ishizuka, O., and Komazawa, M.: Geological map of Japan $1: 200,000$, Ogasawara Shoto, Geological Survey of Japan, AIST, Tsukuba, Japan, 46 pp., 2009 (in Japanese with English abstract).
Umino, S., Kitamura, K., Kanayama, K., Tamura, A., Sakamoto, N., Ishizuka, O., and Arai, S.: Thermal and chemical evolution of the subarc mantle revealed by spinel-hosted melt inclusions in boninite from the Ogasawara (Bonin) Archipelago, Japan, Geology, 43, 151-154, https://doi.org/10.1130/G36191.1, 2015.

Umino, S., Kanayama, K., Kitamura, K., Tamura, A., Ishizuka, O., Senda, R., and Arai, S.: Did boninite originate from the heterogeneous mantle with recycled ancient slab?, Isl. Arc, 27, e12221, https://doi.org/10.1111/iar.12221, 2018.

Vollmer, F.: Orient 3: a new integrated software program for orientation data analysis, kinematic analysis, spherical projections, and Schmidt plots, in: Geological Society of America Abstracts with Programs, Baltimore, Maryland, USA, vol. 47, p. 49, 2015.

Wada, I. and King, S.: Dynamics of Subducting Slabs: Numerical Modeling and Constraints from Seismology, Geoid, Topography, Geochemistry, and Petrology, in: Treatise on Geophysics, Elsevier, UK, 339-391, 2015.

Walker, G. P. L.: Morphometric study of pillow-size spectrum among pillow lavas, B. Volcanol., 54, 459-474, https://doi.org/10.1007/BF00301392, 1992.

Watanabe, A. and Kuroda, N.: Quartz-bearing boninite from northern Chichi-jima, Bonin Islands?: Magma mixing of boninite with quartz dacite, Geosci. Reports Shizuoka Univ., 27, 1-9, https://doi.org/10.14945/00000365, 2000.

Weyer, S., Münker, C., and Mezger, K.: Nb/Ta, Zr/Hf and REE in the depleted mantle: Implications for the differentiation history of the crust - mantle system, Earth Planet. Sc. Lett., 205, 309324, https://doi.org/10.1016/S0012-821X(02)01059-2, 2003.

Whattam, S. A. and Stern, R. J.: The "subduction initiation rule": a key for linking ophiolites, intra-oceanic forearcs, and subduction initiation, Contrib. Mineral. Petrol., 162, 1031-1045, https://doi.org/10.1007/s00410-011-0638-z, 2011.

Whattam, S. A. and Stern, R. J.: Late Cretaceous plume-induced subduction initiation along the southern margin of the Caribbean and NW South America: The first documented example with implications for the onset of plate tectonics, Gondwana Res., 27, 38-63, https://doi.org/10.1016/J.GR.2014.07.011, 2015.

Workman, R. K. and Hart, S. R.: Major and trace element composition of the depleted MORB mantle (DMM), Earth Planet. Sc. Lett., 231, 53-72, https://doi.org/10.1016/j.epsl.2004.12.005, 2005.

Wu, J., Suppe, J., Lu, R., and Kanda, R.: Philippine Sea and East Asian plate tectonics since $52 \mathrm{Ma}$ constrained by new subducted slab reconstruction methods, J. Geophys. Res.-Sol. Ea., 121, 4670-4741, https://doi.org/10.1002/2016JB012923, 2016.

Yajima, K. and Fujimaki, H.: High-Ca and low-Ca boninites from Chichijima, Bonin (Ogasawara) archipelago, Japanese Mag. Mineral. Petrol. Sci., 30, 217-236, https://doi.org/10.2465/gkk.30.217, 2001.

Yamazaki, T., Takahashi, M., Iryu, Y., Sato, T., Oda, M., Takayanagi, H., Chiyonobu, S., Nishimura, A., Nakazawa, T., and Ooka, T.: Philippine Sea Plate motion since the Eocene estimated from paleomagnetism of seafloor drill cores and gravity cores, Earth Planets Space, 62, 495-502, https://doi.org/10.5047/eps.2010.04.001, 2010.

Yumul, G. P.: Varying mantle sources of supra-subduction zone ophiolites: REE evidence from the Zambales Ophiolite Complex, Luzon, Philippines, Tectonophysics, 262, 243-262, https://doi.org/10.1016/0040-1951(96)00013-3, 1996. 
Yumul, G. P., Dimalanta, C. B., and Jumawan, F. T.: Geology of the southern Zambales Ophiolite Complex, Luzon, Philippines, Isl. Arc, 9, 542-555, https://doi.org/10.1111/j.14401738.2000.00300.x, 2000.

Yumul Jr., G. P.: Multi-stage melting, evolving mantle sources and ophiolite generation: Constraints from the Zambales ophiolite complex, Philippines, PhD Thesis, University of Tokyo, Tokyo, Japan, 1990.

Yumul Jr., G. P., Datuin, R. T., and Manipon, J. C.: Geology and geochemistry of the Cabangan-San Antonio massifs, Zambales ophiolite complex, Philippines: Tectonically juxtaposed marginal basin-island arc terranes, J. Geol. Soc. Philipp., 45, 69100, 1990.

Yumul Jr., G. P., Dimalanta, C. B., Faustino, D. V., and De Jesus, J. V: Translation and docking of an arc terrane: geological and geochemical evidence from the southern Zambales Ophiolite Complex, Philippines, Tectonophysics, 293, 255-272, https://doi.org/10.1016/S0040-1951(98)00096-1, 1998.

Zahirovic, S., Seton, M., and Müller, R. D.: The Cretaceous and Cenozoic tectonic evolution of Southeast Asia, Solid Earth, 5, 227-273, https://doi.org/10.5194/se-5-227-2014, 2014.
Zahirovic, S., Matthews, K. J., Flament, N., Müller, R. D. Hill, K. C., Seton, M., and Gurnis, M.: Tectonic evolution and deep mantle structure of the eastern Tethys since the latest Jurassic, Earth-Sci. Rev., 162, 293-337, https://doi.org/10.1016/J.EARSCIREV.2016.09.005, 2016.

Zakariadze, G. S.: Petrology of basalts of holes 447A, 449, and 450, South Philippine Sea transect, Deep Sea Drilling Project Leg 59, edited by: Dmitriev, L. V., Sobolev, A. V., Sushchevskaya, N. M., Kroenke, L., Scott, R. B., Balshaw, K. M., Brassell, S. C., Chotin, P., Heiman, M. E., Ishii, T., Keating, B. H., Martini, E., Mattey, D. P., Rodolfo, K. S., Sartori, R., Theyer, F., Usher, J. L., Zakariadze, G., and Orlofsky, S., Initial Reports Deep Sea Drill. Proj., 59, 669-680, https://doi.org/10.2973/dsdp.proc.59.129.1981, 1981.

Zanetti, A., D'Antonio, M., Spadea, P., Raffone, N., Vannucci, R., and Bruguier, O.: Petrogenesis of mantle peridotites from the Izu-Bonin-Mariana (IBM) forearc, Ofioliti, 31, 189-206, https://doi.org/10.4454/ofioliti.v31i2.340, 2006. 